\title{
Petrology and geochemistry of Miocene igneous rocks on Rebun Island, northern Hokkaido, Japan
}

\author{
Yuka HiRAHARA $^{*}$ and Kenji SHUTo ${ }^{* *}$ \\ "IFREE, JAMSTEC, 2-15 Natsushima-cho, Yokosuka 237-0061, Japan \\ ${ }^{* *}$ Faculty of Science, Niigata University, 8050 Igarashi-ninocho, Niigata 950-2181, Japan
}

\begin{abstract}
We identify four stages in the Miocene magmatic activity on Rebun Island, northern Hokkaido, Japan: Stage I (18 Ma), Stage II (13 Ma), Stage III (10 Ma), and Stage IV ( $<10 \mathrm{Ma})$. Stages I and II produced small intrusions of dolerite and dacite, respectively. During Stage III, basalt to andesite lavas erupted, while the magmatism of Stage IV formed large intrusions of dolerite, porphyrite, and andesite with dacitic veins. The large variations of major and trace element compositions of Stage III and IV rocks can be explained by considering the fractional crystallization of a basaltic melt; however, the proportion of phases fractionating is different for the two stages. Further, in comparison to Stage IV rocks, Stage III rocks have lower concentrations of incompatible elements and higher $\mathrm{Zr} / \mathrm{Y}$ ratios with similar $\mathrm{Zr} / \mathrm{Nb}$ ratios, suggesting higher degree of partial melting of the source material. The initial values of ${ }^{87} \mathrm{Sr} /{ }^{86} \mathrm{Sr}(\mathrm{SrI})$ and ${ }^{143} \mathrm{Nd} /{ }^{144} \mathrm{Nd}(\mathrm{NdI})$ indicate that the rocks of all stages were derived from a common source material, although Stage IV andesites were apparently formed by assimilation fractional crystallization (AFC) during their intrusion into sedimentary rock.

Most of the rocks have SrI and NdI values similar to those of basaltic rocks derived from the upwelling of depleted asthenospheric mantle during the spreading of the Japan Sea back-arc basin. In addition, incompatible element signatures obtained for Stage I rock are similar to those obtained for the basalts in the Japan Sea backarc basin. In contrast, Stage II-IV rocks are similar to the basaltic rocks that originated from subduction-related magmatism in northern Hokkaido.
\end{abstract}

Keywords: Miocene Hokkaido volcanism, Rebun Island, Fractional crystallization, AFC, Sr-Nd isotopes, Depleted asthenospheric mantle

\section{INTRODUCTION}

Miocene volcanic rocks are widely distributed around northern Hokkaido, Japan, behind the junction of the Kurile and northeast (NE) Japan arcs, between the Kurile and Japan Basins (Fig. 1). It is considered that the earliest Miocene magmatism in this region occurred on Rebun Island, located off the northeastern coast of Hokkaido, and Cape Soya, northeastern Hokkaido, at around $18 \mathrm{Ma}$ (Fig. 1). Similar ages have been reported for the magmatic activity in the Central Hokkaido area (e.g., Aoyama basalt from the Hamamasu area: Okamura et al., 1991; Okamura et al., 2000). The magmatism then migrated southward with time, resulting in the present-day pattern of volcanic activity (Watanabe and Yamaguchi, 1988; Kokubu et al., 1994; Yahata and Nishito, 1995). From 14 to 9 Ma, north-

doi:10.2465/jmps.070421

Y. Hirahara, hiraharay@jamstec.go.jp Corresponding author

K. Shuto, shuto@geo.sc.niigata-u.ac.jp ern Hokkaido was the most volcanically active region (e.g., Goto et al., 1995). The volcanic rocks of this period have geochemical signatures similar to the rocks formed by subduction zone magmatism, but there is no systematic spatial variation in their geochemical composition (Nakagawa et al., 1993; Goto et al., 1995; Okamura et al., 1995).

Several tectonic models have been proposed to explain the magmatism that occurred from 14 to $9 \mathrm{Ma}$ : (1) spreading within the Kurile back-arc basin (Goto et al., 1995; Ikeda, 1998; Ikeda et al., 2000; Yamashita et al., 1999); (2) an increase in the dip angle of the subducting Pacific Plate, which resulted in an injection of hot asthenospheric mantle into the overlying lithospheric mantle (Watanabe, 1995); and (3) collisional tectonics involving the Eurasian, Okhotsk, and Pacific Plates following the spreading of the Japan Sea back-arc basin (Okamura et al., 1995). Shuto et al. (2004) argued that the magma was generated from a common asthenospheric source that up- 


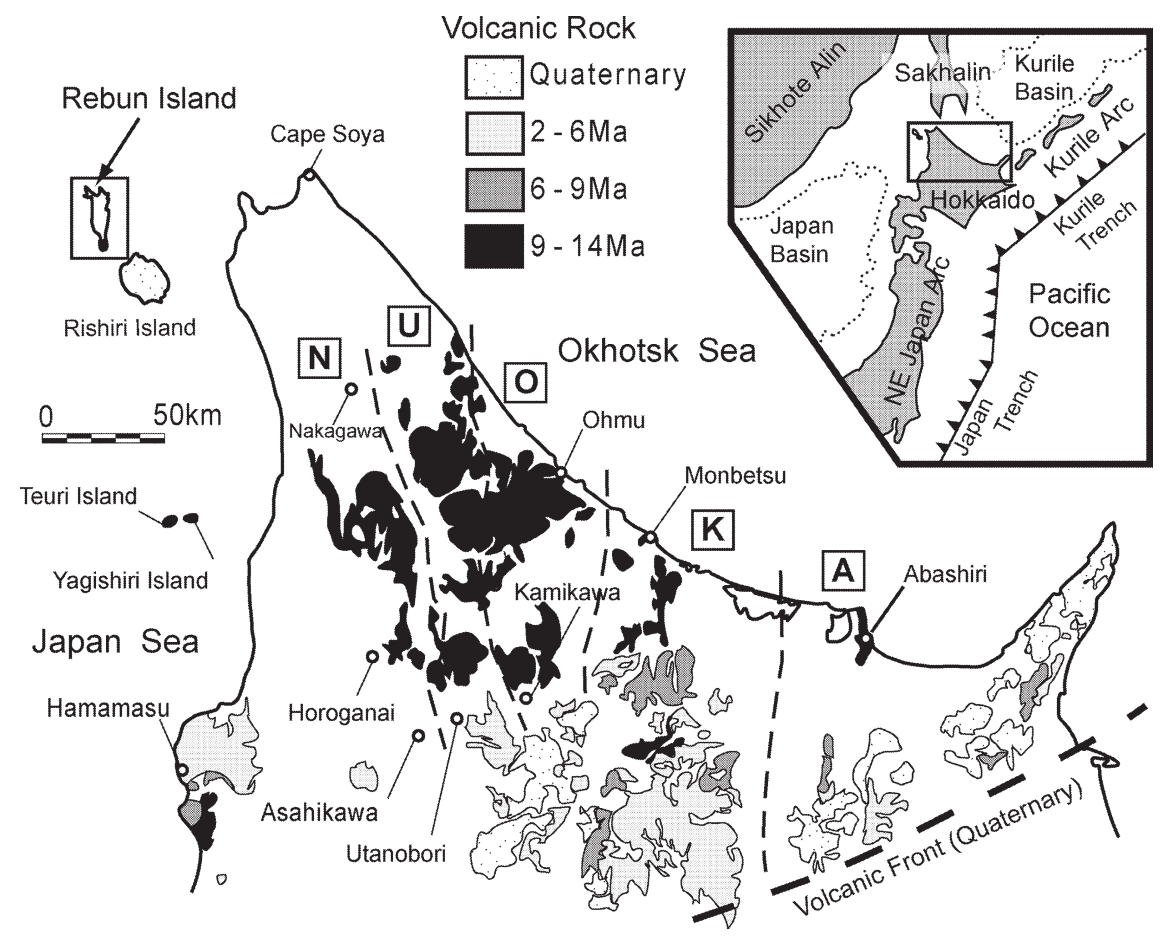

Figure 1. Locality map for Rebun Island and the distribution of Cenozoic volcanic rocks in northern Hokkaido, Japan (from Okamura et al., 1995). The boundaries of volcanic zones are modified from Okamura et al. (1995). N, Nakagawa volcanic zone; U, Utanobori volcanic zone; O, Ohmu volcanic zone; K, Kitami volcanic zone; A, Abashiri volcanic zone. welled into the subcontinental lithosphere beneath northern Hokkaido and back-arc side of the NE Japan arc during the spreading of the Japan Sea and Kurile back-arc basins in Miocene-Quaternary.

In contrast, few studies have considered the relationship between tectonics and magmatism prior to $14 \mathrm{Ma}$. Goto and Wada (1991) reported a K-Ar age of 18.2 Ma for alkali dolerite on Rebun Island. The Japan Sea is considered to have undergone spreading from approximately 28 to $18 \mathrm{Ma}$ (Tamaki et al., 1992), which suggests that the alkaline basaltic magmatism on Rebun Island occurred during the spreading of the Japan Sea back-arc basin. Otofuji and Masuda (1984) and Otofuji et al. (1994) suggested that the spreading of the Japan Sea was resulted in the eastward migration of the Japan arc, away from the East Asian continental margin. Similar basaltic magmatism was also reported along the East Asian continental margin area (e.g., Sakhalin: Okamura et al., 1998; Okamura et al., 2005).

The magmatic activity on Rebun Island occurred in the period prior to $14 \mathrm{Ma}$ (during the initiation of magmatism in northern Hokkaido) and 14 to $9 \mathrm{Ma}$ (during the most intense magmatic activity in northern Hokkaido) (Goto and Wada, 1991; Goto et al., 1995; Goto, 1997; Goto and McPhie, 1998). Therefore, it is important to clarify the origin of the magmatic activity on Rebun Island in order to understand the evolution of magmatism in northern Hokkaido.

In the present study, we report major element, trace element, and $\mathrm{Sr}-\mathrm{Nd}$ isotope compositions of Miocene igneous rocks on Rebun Island and describe the variations in their geochemical signatures. We also discuss the relationship between the magmatism on Rebun Island and that along the East Asian continental margin area (including northern Hokkaido).

\section{GEOLOGY OF REBUN ISLAND}

Okamura et al. (1995) divided the Cenozoic igneous rocks in northern Hokkaido into five volcanic zones: Nakagawa, Utanobori, Ohmu, Kitami, and Abashiri volcanic zones (from the Japan Sea side towards the Okhotsk Sea) (Fig. 1). Although Rebun Island is located in the Japan Sea along with Yagihiri and Teuri Islands (Fig. 1), Okamura et al. (1995) assigned these islands to the Nakagawa volcanic zone.

Figure 2 shows a geological map and stratigraphic column of Rebun Island. The Miocene rocks on this island consist of the Motochi, Kafuka, Meshikuni, and Hamanaka Formations. They lie unconformably on the Rebun Group, which belong to the early Cretaceous RebunKabato volcanic belt (Komatsu, 1985).

The Motochi Formation occurs in the central and southern parts of the island and consists of mudstones, sandstones, and conglomerates. In the southern part of the island, the formation is intruded by a dacite mass known as the Momoiwa dome (Goto and Mcphie, 1998). The Kafuka Formation, which occurs in the southern part of 


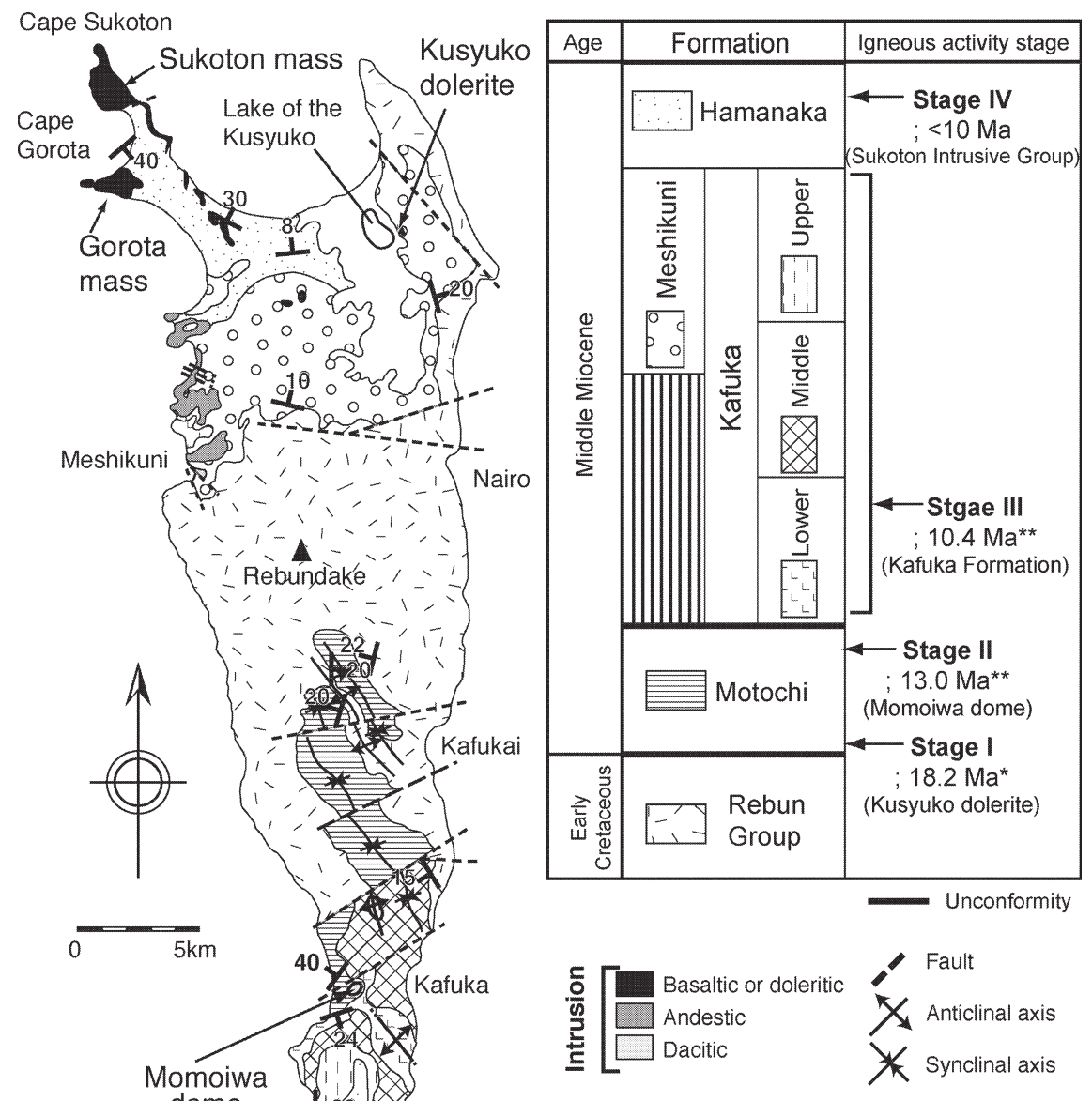

Figure 2. Geological map and stratigraphic column of rocks from Rebun Island. The ages of igneous activity have been obtained from ${ }^{*}$, Goto and Wada (1991) and ${ }^{* *}$, Goto et al. (1995). the island, lies unconformably on the Motochi Formation. It is divided into three units: a lower unit comprising basaltic to andesitic volcanic breccias, a middle unit containing epiclastic rocks including andesitic to dacitic lavas, and an upper unit consisting of sandstones, mudstones, and conglomerates with andesitic lava. The Meshikuni Formation, which is restricted to the north of the island, consists of sandstones, mudstones, and conglomerates that contain shallow-marine molluscs (Noda and Hoyanagi, 1993). It overlies a dolerite mass known as the Kusyuko dolerite around the Kusyuko Lake (Goto and Wada, 1991). The Hamanaka Formation, found in both the southern and northern parts of the island, overlies the Kafuka and Meshikuni Formations and consists of diatomaceous mudstones and siltstones. In the northwestern parts of the island, the Meshikuni and Hamanaka Formations are intruded by andesite, dolerite, and porphyrite masses (collectively known as the Sukoton Intrusive Group; Goto et al., 1995). The largest intrusions of the group occur in the Hamanaka Formation at Cape Gorota (Gorota mass) and Cape Sukoton (Sukoton mass) (Fig. 2).

The Miocene magmatic activity on Rebun Island can be divided into four stages (Stages I-IV) according to the results of $\mathrm{K}-\mathrm{Ar}$ dating performed in previous studies. The magmatic activity for Stages I and II occurred at approximately $18 \mathrm{Ma}$ and $13 \mathrm{Ma}$, respectively. The former produced the Kusyuko dolerite (Goto and Wada, 1991), whereas the latter formed the Momoiwa dome (Goto et al., 1995; Goto and Mcphie, 1998). The magmatic activity during Stage III produced volcanic breccias and/or lavas (the Kafuka Formation) at approximately $10 \mathrm{Ma}$ (Goto et al., 1995), while Stage IV produced the Sukoton Intrusive Group, which is likely to have intruded into wet, poorly consolidated sediments of the Hamanaka Formation (Goto, 1997; Hirahara and Shuto, 2003). Although age data are lacking, the magmatic activity that produced the Sukoton Intrusive Group is probably more recent than that associated with the Kafuka Formation. We describe the age, occurrence, and petrography of rocks from each stage in the next section. The mineral assemblages are listed in Table 1. 
Table 1. Modal mineral assemblages of the igneous rocks from Rebun Island

\begin{tabular}{|c|c|c|c|c|c|c|c|c|}
\hline \multirow[b]{2}{*}{ Locality } & \multirow[b]{2}{*}{ Rock Type } & \multirow{2}{*}{$\begin{array}{l}\text { Sample } \\
\mathrm{SiO}_{2} \\
(\mathrm{wt} \%)\end{array}$} & \multicolumn{4}{|c|}{ Phenocryst (vol\%) } & \multirow[b]{2}{*}{$\begin{array}{l}\text { Fe-Ti } \\
\text { oxides } \\
(\mathrm{mm})\end{array}$} & \multirow[b]{2}{*}{$\begin{array}{c}\text { GM* } \\
\text { (vol\%) }\end{array}$} \\
\hline & & & $\begin{array}{c}\mathrm{Pl} \\
(\mathrm{mm})\end{array}$ & $\begin{array}{c}\mathrm{Ol} \\
(\mathrm{mm})\end{array}$ & $\begin{array}{l}\mathrm{Cpx} \\
(\mathrm{mm})\end{array}$ & $\begin{array}{l}\text { Opx } \\
(\mathrm{mm})\end{array}$ & & \\
\hline \multicolumn{9}{|c|}{ Stage I } \\
\hline $\begin{array}{l}\text { Kusyuko } \\
\text { intrusion }\end{array}$ & Cpx dolerite & Ku101 & $\begin{array}{c}85.4 \\
(0.6-0.16) \\
\end{array}$ & & $\begin{array}{c}3.7 \\
(0.3-0.6) \\
\end{array}$ & & $\begin{array}{c}1.6 \\
(<0.3) \\
\end{array}$ & 9.3 \\
\hline \multicolumn{9}{|c|}{ Stage II } \\
\hline $\begin{array}{l}\text { Momoiwa } \\
\text { dome }\end{array}$ & Cpx dacite & $\begin{array}{c}\mathrm{Mo05} \\
62.9 \\
\end{array}$ & $\begin{array}{c}4.8 \\
(<1.0) \\
\end{array}$ & & $\begin{array}{c}0.2 \\
(<0.5)\end{array}$ & & $\begin{array}{c}+ \\
(<0.5) \\
\end{array}$ & 95.0 \\
\hline \multicolumn{9}{|c|}{ Stage III } \\
\hline Lower unit: & Opx bearning & St06 & 40.0 & 2.2 & 4.2 & 0.2 & 2.6 & 50.8 \\
\hline Breccia & Ol-Cpx basalt & 52.5 & $(0.3-0.9)$ & $(0.3-0.9)$ & $(0.3-0.9)$ & $(0.3-0.9)$ & & \\
\hline Lower unit: & Ol-Opx & Nk08 & 59.7 & 6.8 & & 4.2 & 2.1 & 27.2 \\
\hline Breccia & basaltic andesite & 54.3 & $(0.3-0.9)$ & $(0.3-0.9)$ & & $(0.3-0.9)$ & & \\
\hline Lower unit: & $\mathrm{Ol}$ & St09 & 26.2 & 2.7 & & & & 71.1 \\
\hline Dyke & basaltic andesite & 54.6 & $(0.3-0.9)$ & $(0.3-0.9)$ & & & & \\
\hline Lower unit: & Opx-Cpx & Nk07 & 9.4 & & 1.4 & 0.4 & 0.2 & 88.6 \\
\hline Breccia & andesite & 59.7 & $(0.3-0.9)$ & & $(0.3-0.9)$ & $(0.3-0.9)$ & & \\
\hline Lower unit: & $\mathrm{Cpx}$ & St12 & 16.6 & & 0.2 & & & 83.2 \\
\hline Dyke & andesite & 60.3 & $(0.3-0.9)$ & & $(0.3-0.9)$ & & & \\
\hline $\begin{array}{l}\text { Middle unit: } \\
\text { Lava }\end{array}$ & $\begin{array}{l}\text { Cpx } \\
\text { andesite }\end{array}$ & $\begin{array}{c}\text { Reb01 } \\
59.0\end{array}$ & $\begin{array}{c}31.3 \\
(0.3-0.9)\end{array}$ & & $\begin{array}{c}6.4 \\
(0.3-0.9)\end{array}$ & & 0.8 & 61.5 \\
\hline \multicolumn{9}{|c|}{ Stage IV } \\
\hline $\begin{array}{l}\text { Gorota } \\
\text { intrusion }\end{array}$ & Ol-Cpx dolerite & $\begin{array}{c}\text { Go55 } \\
54.0\end{array}$ & $\begin{array}{c}68.3 \\
(0.6-2.4)\end{array}$ & $\begin{array}{c}2.5 \\
(0.6-0.9)\end{array}$ & $\begin{array}{c}6.6 \\
(0.2-0.9)\end{array}$ & & $\begin{array}{c}2.2 \\
(0.1-0.3)\end{array}$ & 20.4 \\
\hline $\begin{array}{l}\text { Sukoton } \\
\text { intrusion }\end{array}$ & Ol-Cpx dolerite & $\begin{array}{l}\mathrm{Sc} 04 \\
54.6\end{array}$ & $\begin{array}{c}68.7 \\
(0.6-1.8)\end{array}$ & $\begin{array}{c}1.0 \\
(0.6-0.9)\end{array}$ & $\begin{array}{c}5.8 \\
(0.3-0.6)\end{array}$ & & $\begin{array}{c}2.0 \\
(0.1-0.6)\end{array}$ & 23.5 \\
\hline Gorota & Opx-Cpx & Go30 & 76.1 & & 11.5 & 4.4 & 2.1 & 5.9 \\
\hline intrusion & dolerite & 54.8 & $(0.3-2.4)$ & & $(0.1-0.6)$ & $(0.9-1.5)$ & $(0.1-0.3)$ & \\
\hline Sukoton & Opx-Cpx & Sc239 & 63.6 & & 11.6 & 1.0 & 2.0 & 21.8 \\
\hline intrusion & dolerite & 54.9 & $(1.3-3.2)$ & & $(0.8-1.9)$ & $(1.6)$ & $(0.1-0.3)$ & \\
\hline Sukoton & Cnx dolerite & $\mathrm{Sc} 45$ & 64.8 & & 7.3 & & 0.7 & 27.2 \\
\hline intrusion & Cpx dolerite & 55.4 & $(3.0<)$ & & $(0.6-1.2)$ & & $(0.3-1.8)$ & \\
\hline Gorota & Opx-Cpx & Go200 & 72.3 & & 12.8 & 0.3 & 2.5 & 12.1 \\
\hline intrusion & porphyrite & 59.5 & $(<6.0)$ & & $(2.4-4.2)$ & $(>1.0)$ & $(0.1-0.6)$ & \\
\hline Sukoton & Opx-Cpx & Sc198 & 74.2 & & 7.0 & 4.1 & 6.0 & 8.7 \\
\hline intrusion & porphyrite & 59.5 & $(>3.0)$ & & $(0.3-3.0)$ & $(>1.0)$ & $(0.3-0.6)$ & \\
\hline $\begin{array}{l}\text { Segregation } \\
\text { vein }\end{array}$ & Cpx dacite & $\begin{array}{c}\mathrm{Gt} 34 \mathrm{~V} \\
64.6\end{array}$ & $\begin{array}{c}8.3 \\
(0.6-1.8)\end{array}$ & & $\begin{array}{c}0.8 \\
(0.3-2.4)\end{array}$ & & $\begin{array}{c}+ \\
(0.2)\end{array}$ & 90.9 \\
\hline
\end{tabular}

Ol, olivine; Cpx, clinopyroxene; Opx, orthopyroxene; Pl, plagioclase; GM, groundmass; +, trace.

* Interstitial material in dolerite and porphyrite.

\section{AGE AND PETROGRAPHY OF ROCK SAMPLES}

\section{Stage I}

The Kusyuko dolerite occurs in the form of a small sheetlike intrusion, and has an exposed area with a length and width of $10 \mathrm{~m}$ and more than $2 \mathrm{~m}$, respectively, beneath the conglomerate of the Meshikuni Formation (Goto and Wada, 1991). The minerals in the dolerite are plagioclase, clinopyroxene, and $\mathrm{Fe}-\mathrm{Ti}$ oxides. Plagioclase and clinopyroxene occur as euhedral to subhedral poikilitic phenocrysts; large clinopyroxene grains occupy the interstices between the plagioclase grains. The age of the dolerite yields a K-Ar age of $18.2 \pm 1.2 \mathrm{Ma}$ (Goto and Wada, 1991). Goto et al. (1995) proposed that the magmatic activity in Stage I is related to the alkali basaltic magmatism at Cape Soya.

\section{Stage II}

The Momoiwa dome, 200-300 $\mathrm{m}$ diameter and $190 \mathrm{~m}$ in height, intruded into wet, poorly consolidated sediments (the Motochi Formation). Goto and Mcphie (1998) have detailed the internal structure of the dome. The dacite consists of fresh, euhedral plagioclase and $\mathrm{Fe}-\mathrm{Ti}$ oxides as phenocrysts, with a pilotaxitic groundmass of plagio- 
Table 2. $\mathrm{Sr}, \mathrm{Rb}, \mathrm{Sm}$, and $\mathrm{Nd}$ contents (ppm) and $\mathrm{Sr}-\mathrm{Nd}$ isotopic composition determined for the igneous rocks from Rebun Island

\begin{tabular}{|c|c|c|c|c|c|c|c|c|c|c|c|}
\hline Locality & $\begin{array}{c}\text { Sample } \\
\text { No. }\end{array}$ & $\begin{array}{c}\mathrm{SiO}_{2} \\
(\mathrm{wt} \%)\end{array}$ & $\begin{array}{c}\mathrm{Rb} \\
(\mathrm{ppm})\end{array}$ & $\begin{array}{c}\mathrm{Sr} \\
(\mathrm{ppm})\end{array}$ & ${ }^{87} \mathrm{Sr} /{ }^{86} \mathrm{Sr}$ & $2 \sigma$ & $\begin{array}{c}\mathrm{Sm} \\
(\mathrm{ppm})\end{array}$ & $\begin{array}{c}\mathrm{Nd} \\
(\mathrm{ppm})\end{array}$ & ${ }^{143} \mathrm{Nd} /{ }^{144} \mathrm{Nd}$ & $2 \sigma$ & $\mathrm{NdI}$ \\
\hline \multicolumn{12}{|c|}{ Stage I (18.2 Ma*) } \\
\hline Kusyuko & Mk01 & 49.3 & 20.9 & 416 & 0.703753 & \pm 0.000014 & 5.55 & 18.3 & 0.512886 & \pm 0.0000140 .703716 & 0.512864 \\
\hline \multicolumn{12}{|c|}{ Stage II (13.0 Ma**) } \\
\hline Momoiwa & Mo02 & 62.4 & 27.2 & 490 & 0.703603 & \pm 0.000014 & 4.14 & 15.7 & 0.512905 & \pm 0.0000140 .703573 & 0.512891 \\
\hline \multicolumn{12}{|c|}{ Stage III (10.4 Ma**) } \\
\hline Lower unit & St17 & 54.2 & 9.19 & 353 & 0.703878 & \pm 0.000010 & 2.93 & 11.1 & 0.512898 & \pm 0.0000130 .703867 & 0.512888 \\
\hline Lower unit & St19 & 54.5 & 10.6 & 348 & 0.703997 & \pm 0.000023 & 2.92 & 11.1 & 0.512913 & \pm 0.0000150 .703985 & 0.512903 \\
\hline Lower unit & Nk09 & 54.2 & 11.5 & 363 & 0.703938 & \pm 0.000012 & 3.14 & 12.2 & 0.512869 & \pm 0.0000100 .703925 & 0.512859 \\
\hline Lower unit & Nk08 & 54.3 & 10.0 & 363 & 0.703898 & \pm 0.000014 & 3.15 & 12.2 & 0.512863 & \pm 0.0000130 .703887 & 0.512853 \\
\hline Lower unit & St07 & 52.3 & 1.79 & 396 & 0.703876 & \pm 0.000014 & 2.93 & 9.85 & 0.512902 & \pm 0.0000100 .703874 & 0.512892 \\
\hline Lower unit & St12 & 60.3 & 25.0 & 318 & 0.703833 & \pm 0.000009 & 4.10 & 15.3 & 0.512896 & \pm 0.0000140 .703801 & 0.512885 \\
\hline Lower unit & St06 & 52.5 & 2.82 & 385 & 0.703854 & \pm 0.000010 & 2.93 & 9.85 & 0.512863 & \pm 0.0000140 .703851 & 0.512851 \\
\hline Lower unit & S105 & 54.6 & 12.2 & 359 & 0.703795 & \pm 0.000016 & 2.96 & 9.83 & 0.512879 & \pm 0.0000140 .703781 & 0.512867 \\
\hline Middle unit & $\mathrm{Rb} 12$ & 64.2 & 38.2 & 305 & 0.704010 & \pm 0.000016 & 3.54 & 16.1 & 0.512910 & \pm 0.0000160 .703943 & 0.512901 \\
\hline \multicolumn{12}{|c|}{ Stage IV $(<10 \mathrm{Ma})$} \\
\hline Sukoton & Sc213 & 59.9 & 28.2 & 247 & 0.704061 & \pm 0.000013 & 6.27 & 22.1 & 0.512809 & \pm 0.0000120 .704014 & 0.512798 \\
\hline Sukoton & Su11 & 54.8 & 14.1 & 367 & 0.703881 & \pm 0.000013 & 3.59 & 17.0 & 0.512887 & \pm 0.0000240 .703865 & 0.512879 \\
\hline Sukoton & Su15 & 54.9 & 20.9 & 332 & 0.703952 & \pm 0.000013 & 3.68 & 15.4 & 0.512824 & \pm 0.0000140 .703926 & 0.512815 \\
\hline Sukoton & Sc150 & 54.6 & 2.28 & 380 & 0.703825 & \pm 0.000014 & 3.68 & 15.6 & 0.512834 & \pm 0.0000110 .703823 & 0.512825 \\
\hline Sukoton & Sc239 & 55.0 & 9.26 & 364 & 0.703806 & \pm 0.000014 & 4.28 & 15.3 & 0.512852 & \pm 0.0000110 .703796 & 0.512841 \\
\hline Sukoton & $\mathrm{Sc} 44$ & 54.4 & 3.41 & 373 & 0.703930 & \pm 0.000011 & 3.94 & 16.5 & 0.512837 & \pm 0.0000120 .703926 & 0.512828 \\
\hline Sukoton & Sc198 & 59.5 & 26.2 & 281 & 0.704080 & \pm 0.000014 & 6.55 & 23.2 & 0.512810 & \pm 0.0000110 .704042 & 0.512799 \\
\hline Sukoton & Sc208 & 55.6 & 9.04 & 373 & 0.703859 & \pm 0.000014 & 4.79 & 17.5 & 0.512866 & \pm 0.0000130 .703849 & 0.512855 \\
\hline Sukoton & Sk12 & 55.9 & 21.5 & 301 & 0.703943 & \pm 0.000012 & 3.52 & 12.7 & 0.512846 & \pm 0.0000140 .703914 & 0.512835 \\
\hline Gorota & Go30 & 54.8 & 25.6 & 306 & 0.703981 & \pm 0.000010 & 3.34 & 13.8 & 0.512827 & \pm 0.0000140 .703947 & 0.512817 \\
\hline
\end{tabular}

clase, Fe-Ti oxides, quartz, and clinopyroxene. Goto et al. (1995) have reported a $\mathrm{K}-\mathrm{Ar}$ age of $13.0 \pm 1.6 \mathrm{Ma}$ for the dome.

\section{Stage III}

Rock samples of Stage III are mainly subaqueous volcaniclastic rocks and feeder dykes that intrude into the lower unit of the Kafuka Formation and grade outward into hyaloclastite. The lower unit consists of orthopyroxeneclinopyroxene basaltic andesite, orthopyroxene-bearing olivine-clinopyroxene basalt, and olivine-orthopyroxene basaltic andesite. The middle and upper units of the formation are dominated by clinopyroxene andesitic lavas, in which olivine phenocrysts are transformed to clay minerals. However, other phenocryst minerals are generally fresh and exhibit euhedral to subhedral morphologies. The rocks from the lower unit show an intersertal-textured groundmass containing plagioclase, glass, and minor Fe-Ti oxides, whereas rocks from the middle and upper units have an intergranular-textured groundmass containing plagioclase, clinopyroxene, Fe-Ti oxides, and glass. The $\mathrm{K}-\mathrm{Ar}$ age of andesite sample from the lower unit was observed to be $10.4 \pm 2.2 \mathrm{Ma}$ (Goto et al., 1995).

\section{Stage IV}

The Gorota mass is a sill or laccolith, with dimensions of $1200 \times 600 \mathrm{~m}$ and a thickness of more than $150 \mathrm{~m}$. It intruded into diatomaceous mudstone and siltstone and has a unique interlayered sill-sediment structure at the southern edge of the mass. Goto (1997) suggested that the structure was formed by parallel injections of magma along bedding planes of wert and pooßrly consolidated sediment. The mass consists of olivine-bearing orthopyroxene-clinopyroxene dolerite, clinopyroxene dolerite, orthopyroxene-clinopyroxene dolerite (the dominant rock type), and clinopyroxene porphyrite in order from its base with the host sedimentary rock. The dolerites show an ophitic texture consisting of anhedral to subhedral plagioclase laths with a length of less than $1 \mathrm{~mm}$ enclosed in large clinopyroxene and orthopyroxene grains with small 
(a)

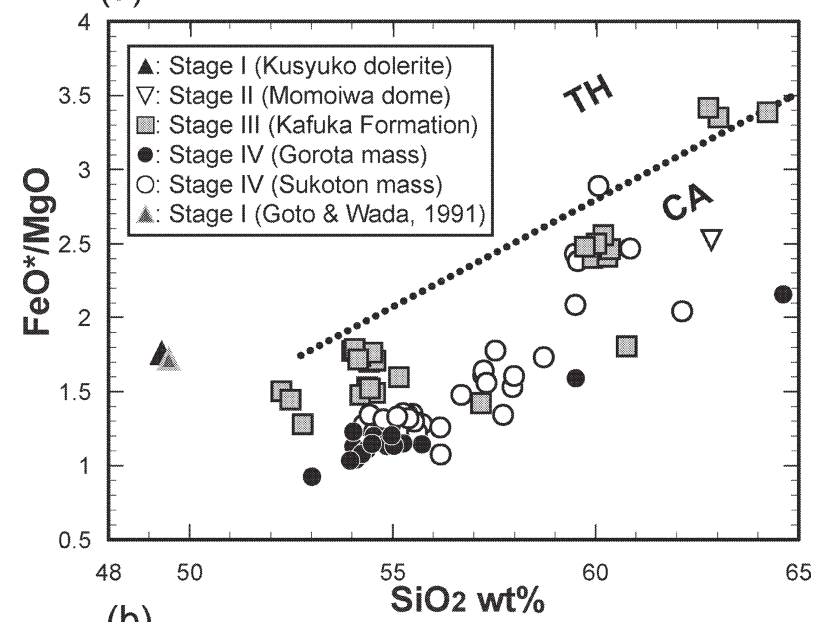

(b)

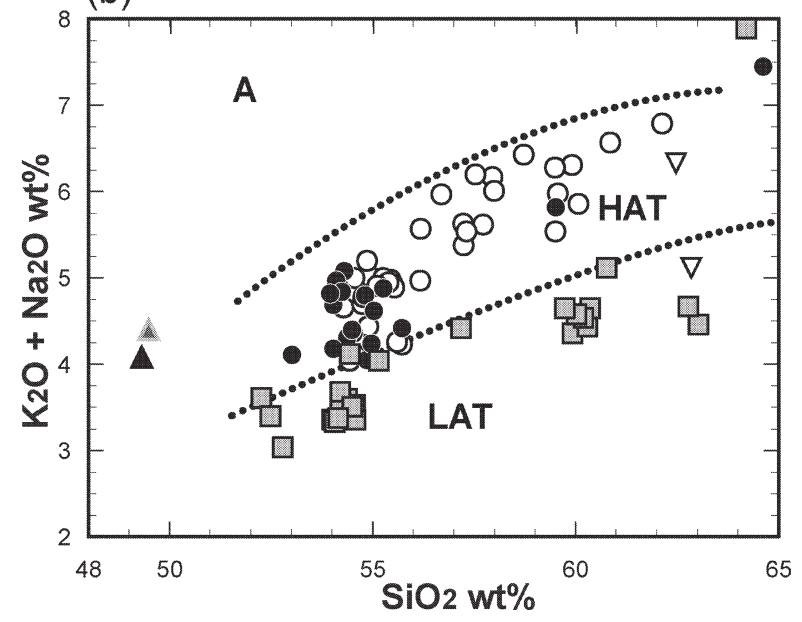

Figure 3. $\mathrm{SiO}_{2}$ versus (a) $\mathrm{FeO}^{*} / \mathrm{MgO}$ and (b) $\mathrm{K}_{2} \mathrm{O}+\mathrm{Na}_{2} \mathrm{O}$ variation diagrams. (a) The boundary (dotted line) of calc-alkaline (CA) and tholeiite (TH) is based on Miyashiro (1974). (b) The boundaries between the low-alumina tholeiite (LAT), high-alumina tholeiite (HAT), and alkaline (A) fields are from the study of Kuno (1968).

amounts of interstitial chloritic material. The clinopyroxene porphyrite is composed of large grains of clinopyroxene, plagioclase, and $\mathrm{Fe}-\mathrm{Ti}$ oxides (up to $3 \mathrm{~mm}$ in length) (Table 1). Segregation veins of aphyric dacite are often observed in the dolerites. The Sukoton mass is a sill swarm, with dimensions of $1600 \times 600 \mathrm{~m}$ and a thickness of more than $240 \mathrm{~m}$, and dips gently eastward. The mass is dominated by orthopyroxene-clinopyroxene dolerite and associated olivine-bearing orthopyroxene-clinopyroxene dolerite, orthopyroxene-clinopyroxene dolerite, clinopyroxene dolerite, and clinopyroxene porphyrite. The petrographic characteristics of the rock types in the Sukoton mass are similar to those of equivalent rock types in the Gorota mass and have been reported in detail by Hirahara and Shuto (2003).

\section{GEOCHEMISTRY}

\section{Analytical methods}

The major element composition and selected trace element composition of whole rocks were measured using fused glass beads by X-ray fluorescence spectrometry (RIGAKU RIX3000) at the Department of Geology, Niigata University, Japan, following the method described by Takahashi and Shuto (1997).

The mineral compositions were analysed by wavelength dispersive X-ray spectroscopy (JEOL JXA8600SX) at the Graduate School of Science and Technology, Niigata University. Generally, the operating conditions involved an acceleration voltage of $15 \mathrm{kV}$ and a beam current of $30 \mathrm{nA}$. The ZAF method was used for online data reduction.

$\mathrm{Sr}-\mathrm{Nd}$ isotopic ratios and $\mathrm{Sm}$ and $\mathrm{Nd}$ concentrations were measured using a Finnigan MAT262 mass spectrometer at Niigata University by following the analytical methods of Kagami et al. (1987, 1989), Miyazaki and Shuto (1998), and Hamamoto et al. (2000). The Sm and $\mathrm{Nd}$ contents of the samples were determined by isotope dilution using a ${ }^{149} \mathrm{Sm}^{-}{ }^{150} \mathrm{Nd}$ mixed spike. $\mathrm{Sr}, \mathrm{Sm}$, and $\mathrm{Nd}$ were extracted from the same solution through an ion-exchange column. The measured $\mathrm{Sr}-\mathrm{Nd}$ isotopic ratios were normalized to ${ }^{86} \mathrm{Sr} /{ }^{88} \mathrm{Sr}=0.1194$ and ${ }^{146} \mathrm{Nd} /{ }^{144} \mathrm{Nd}=0.7219$ for mass fractionation. In this study, by performing multiple analyses of standard NBS987, JNdi-1, and La Jolla (Miyazaki and Shuto, 1998) the following values were obtained: ${ }^{87} \mathrm{Sr} /{ }^{86} \mathrm{Sr}=0.710251 \pm 0.000003(2 \sigma, \mathrm{n}=51)$, ${ }^{143} \mathrm{Nd} /{ }^{144} \mathrm{Nd}=0.512106 \pm 0.000003(2 \sigma, \mathrm{n}=44)$, and ${ }^{143} \mathrm{Nd} /{ }^{144} \mathrm{Nd}=0.511851 \pm 0.000006(2 \sigma, \mathrm{n}=17)$, respectively. We used the following the decay constants for calculating the initial ${ }^{87} \mathrm{Sr} /{ }^{86} \mathrm{Sr}(\mathrm{SrI})$ and ${ }^{143} \mathrm{Nd} /{ }^{144} \mathrm{Nd}$ values $(\mathrm{NdI}): \lambda^{87} \mathrm{Rb}=1.42 \times 10^{-11} / \mathrm{y}$ (Steiger and Jäger, 1977) and $\lambda^{147} \mathrm{Sm}=6.54 \times 10^{-12} / \mathrm{y}$ (Lugmair and Marti, 1978). The total chemical blank in the run during the period of isotope analysis was estimated to be less than $0.52 \mathrm{ng}$ for $\mathrm{Sr}$, $0.04 \mathrm{ng}$ for $\mathrm{Sm}$, and $0.34 \mathrm{ng}$ for Nd. The bulk-rock $\mathrm{Sr}$ and $\mathrm{Nd}$ isotopic compositions are listed in Table 2.

\section{Major and trace element data}

Figure 3 shows the correlations between the $\mathrm{SiO}_{2}$ content and the total $\mathrm{FeO}\left(\mathrm{FeO}^{*}\right) / \mathrm{MgO}$ ratios (Fig. 3a) and between the $\mathrm{SiO}_{2}$ content and $\mathrm{Na}_{2} \mathrm{O}+\mathrm{K}_{2} \mathrm{O}$ (Fig. 3b). The Stage I and II rocks contain 49.3 and 62.4 to $62.9 \mathrm{wt} \%$ $\mathrm{SiO}_{2}$, while Stage III and IV rocks comprise 52.3 to 64.2 and 53.0 to $64.6 \mathrm{wt} \% \mathrm{SiO}_{2}$, respectively. Stage III and IV rocks exhibit relatively constant $\mathrm{FeO}^{*} / \mathrm{MgO}$ ratios with an increase in the $\mathrm{SiO}_{2}$ content, falling in the calc-alkaline 

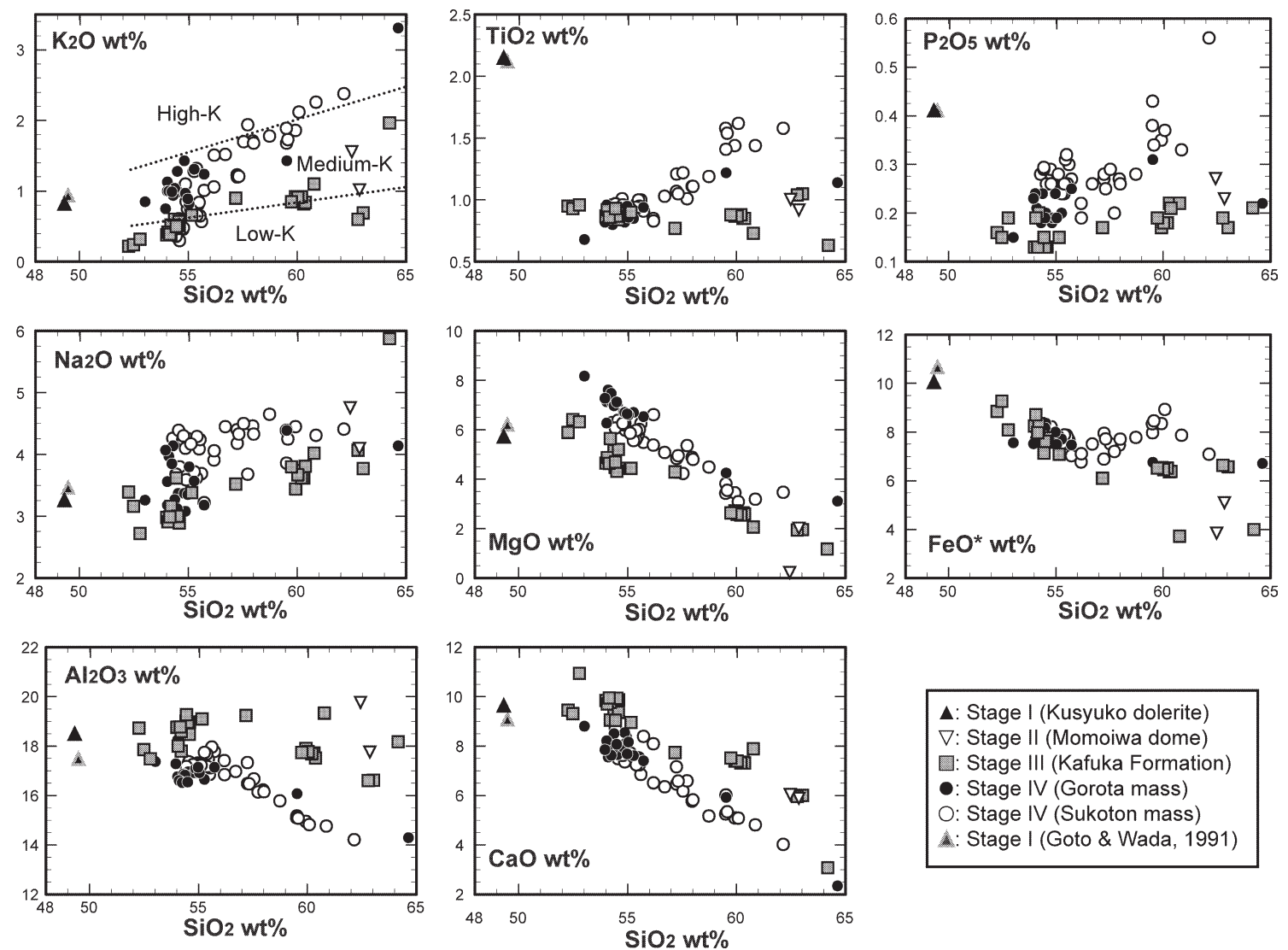

Figure 4. Variation diagrams of $\mathrm{SiO}_{2}$ versus major elements for the igneous rocks from Rebun Island. The boundaries between the low-K, medium-K, and high- $\mathrm{K}$ fields in the $\mathrm{SiO}_{2}-\mathrm{K}_{2} \mathrm{O}$ diagram are from Gill (1981).

magma field (Miyashiro, 1978; Fig. 3a). For a given low $\mathrm{SiO}_{2}$ content $(<55 \mathrm{wt} \%)$, Stage IV rocks have lower $\mathrm{FeO}^{*} /$ $\mathrm{MgO}$ ratios than Stage III rocks. In a plot of $\mathrm{Na}_{2} \mathrm{O}+\mathrm{K}_{2} \mathrm{O}$ versus $\mathrm{SiO}_{2}$ (Fig. 3b), Stage I rock almost have alkali basalt affinities, whereas Stage II, III, and IV rocks have sub-alkaline affinities. Most of the Stage II and III rocks have lower alkali contents than Stage IV rocks; the former rocks belong to the low-alumina tholeiite series, while the latter rocks are assigned to the high-alumina tholeiite series (Kuno, 1968).

Figures 4 and 5 show the correlations between the $\mathrm{SiO}_{2}$ content and the major and trace element concentrations, respectively. The Stage I rock is characterized by elevated $\mathrm{TiO}_{2}, \mathrm{P}_{2} \mathrm{O}_{5}$, and $\mathrm{K}_{2} \mathrm{O}$ contents. This characterization of Stage I rock was reported by Goto and Wada (1991), and their data are plotted in Figure 4. The Stage II rocks, with a high $\mathrm{SiO}_{2}$ content, fall within the compositional variations of the Stage III rocks. The plotting of $\mathrm{SiO}_{2}$ against $\mathrm{K}_{2} \mathrm{O}$ shows that Stage III rocks belong to the low- to medium-K series (Gill, 1981), whereas Stage IV rocks belong to the medium- to high-K series; a few rocks (from the Sukoton mass) are scattered in the low-K field (Fig. 4). The concentrations of $\mathrm{MgO}, \mathrm{Cr}, \mathrm{Ni}, \mathrm{Ba}, \mathrm{Nb}$, and $\mathrm{Zr}$ in Stage III basaltic rocks $\left(\mathrm{SiO}_{2}<55 \mathrm{wt} \%\right)$ are typically lower than those in Stage IV basaltic rocks with similar $\mathrm{SiO}_{2}$ content. The Stage III and IV rocks show large chemical variations: the $\mathrm{MgO}, \mathrm{Al}_{2} \mathrm{O}_{3}, \mathrm{CaO}, \mathrm{Cr}, \mathrm{Ni}$, and $\mathrm{Sr}$ contents generally decrease with an increase in the $\mathrm{SiO}_{2}$ content. However, the trends for both the stages are different. For example, the $\mathrm{TiO}_{2}$ and $\mathrm{P}_{2} \mathrm{O}_{5}$ contents of Stage III rocks are constant with an increase in the $\mathrm{SiO}_{2}$ content, whereas those of Stage IV rocks first increase and then decrease. The $\mathrm{FeO}^{*}$ and $\mathrm{V}$ contents of Stage III rocks decrease with an increase in the $\mathrm{SiO}_{2}$ content, whereas those of Stage IV rocks show a slight increase up to around $60 \mathrm{wt} \% \mathrm{SiO}_{2}$ before decreasing with a further increase in the $\mathrm{SiO}_{2}$ content.

Figure 6 shows the concentrations of incompatible trace elements within the samples rosks from Rebun Island normalized to normal mid-oceanic-ridge basalt (NMORB) (Sun and McDonough, 1989) together with data for basaltic rocks formed in the syn- (from Cape Soya, Hamamasu, Sakhalin, and the Japan Sea) and postspreading stages (from Yagishiri Island and the Pisshiridake Formation in the Nakagawa volcanic zone) of the Japan Sea back-arc basin. All the patterns for the samples 

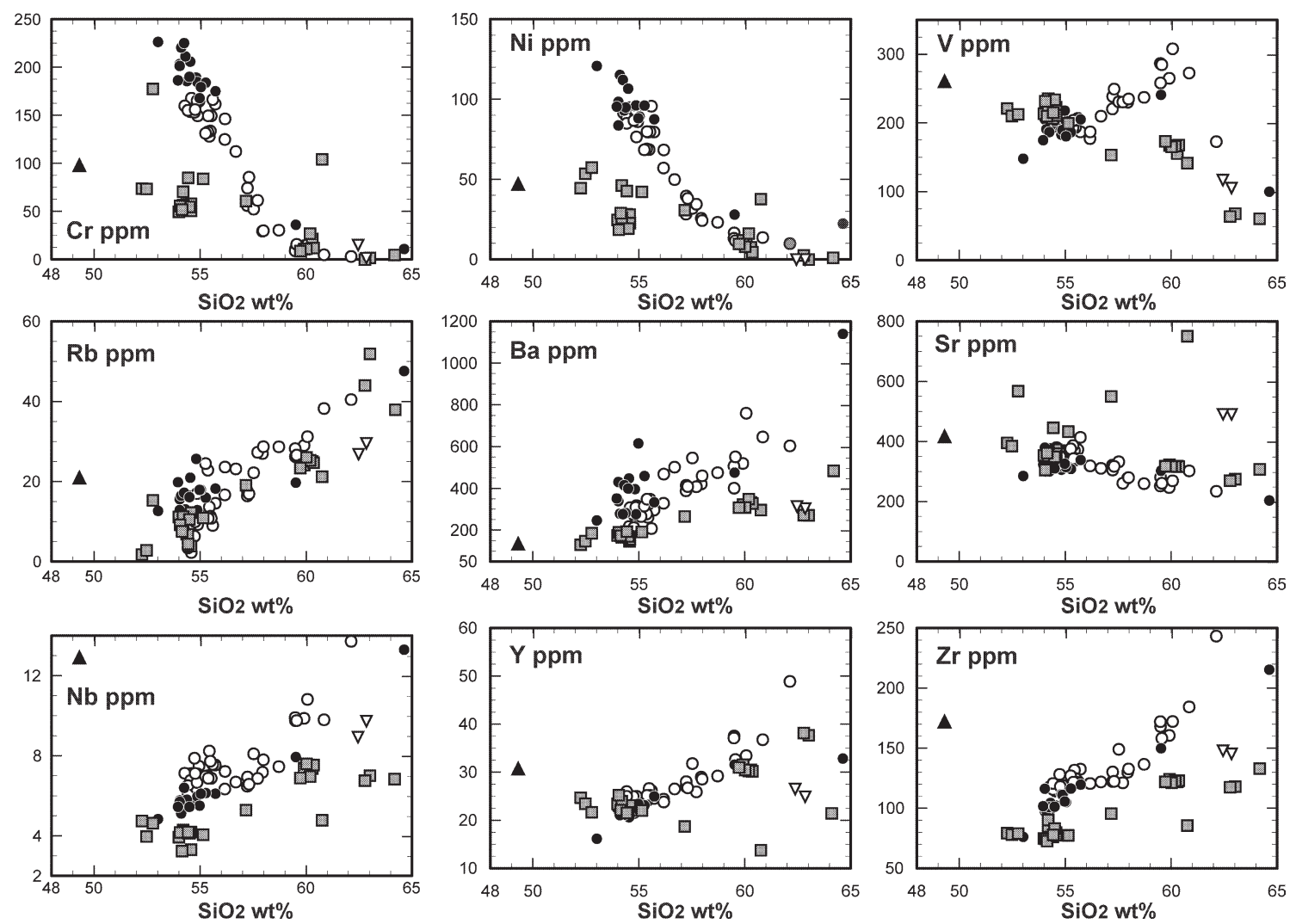

Figure 5. Variation diagrams of $\mathrm{SiO}_{2}$ versus trace elements for the igneous rocks from Rebun Island. Refer to Figure 4 for the key to symbols.

of Rebun Island show a steeply inclined slope with a negative $\mathrm{Nb}$ anomaly, which are typical for subduction-related lavas (Fig. 6a). However, the Stage I rock shows a pattern that is slightly different from those of the other stages, with elevated concentrations of high-field-strength elements (HFSE). The sample from Stage II is a dacite that shows incompatible element patterns and abundances similar to the Stage III and IV rocks. The patterns obtained for Stage III and IV rocks are similar, but the incompatible elements are slightly more abundant in Stage IV rocks than in Stage III rocks.

\section{Sr-Nd isotope data}

The SrI and NdI values of the rocks of all stages obtained from Rebun Island do not vary significantly; their values range from 0.7036 to 0.7040 , and 0.5128 to 0.5129 , respectively. The highest SrI and lowest NdI are found in Stage IV rocks, while the lowest SrI and highest NdI values are observed in Stage II and Stage III rocks, respectively.

The isotope data are plotted in SrI versus NdI diagram (Fig. 7a) together with the data for basaltic rocks formed in the syn- and the post-spreading stages of the Japan Sea back-arc basin. Data for Hokkaido crustal rock
(Maeda and Kagami, 1994) are also plotted in the diagram. Except the data for the basalts from the Hamamasu area (Aoyama basalt), the syn-spreading basaltic rocks define a field within which the SrI and NdI values of the Rebun Island rocks lie. The Aoyama basalts have high SrI and low NdI values (Okamura et al., 1991; Okamura et al., 2000). The basalts produced by the magmatic activity that occurred after the spreading of the Japan Sea backarc basin have lower SrI and higher NdI values as compared to the Rebun samples, except for the samples from the Ohmu area (Shuto et al., 2004).

It is noteworthy that the Stage IV rocks form an array between the depleted MORB mantle (DMM) (Hart, 1988) and the Hokkaido crustal rock, whereas rocks from the other stages plot on the low-SrI and high-NdI side of the array (Figs. 7a and 7b). Figure 8 shows the correlation between the SrI, NdI values and $\mathrm{SiO}_{2}$ content of the Rebun samples. The SrI and NdI values of the Stage III rocks are constant with an increase in the $\mathrm{SiO}_{2}$ contents. On the other hand, the SrI and NdI values of the Stage IV rocks exhibit positive and negative correlations with the $\mathrm{SiO}_{2}$ content, respectively. 

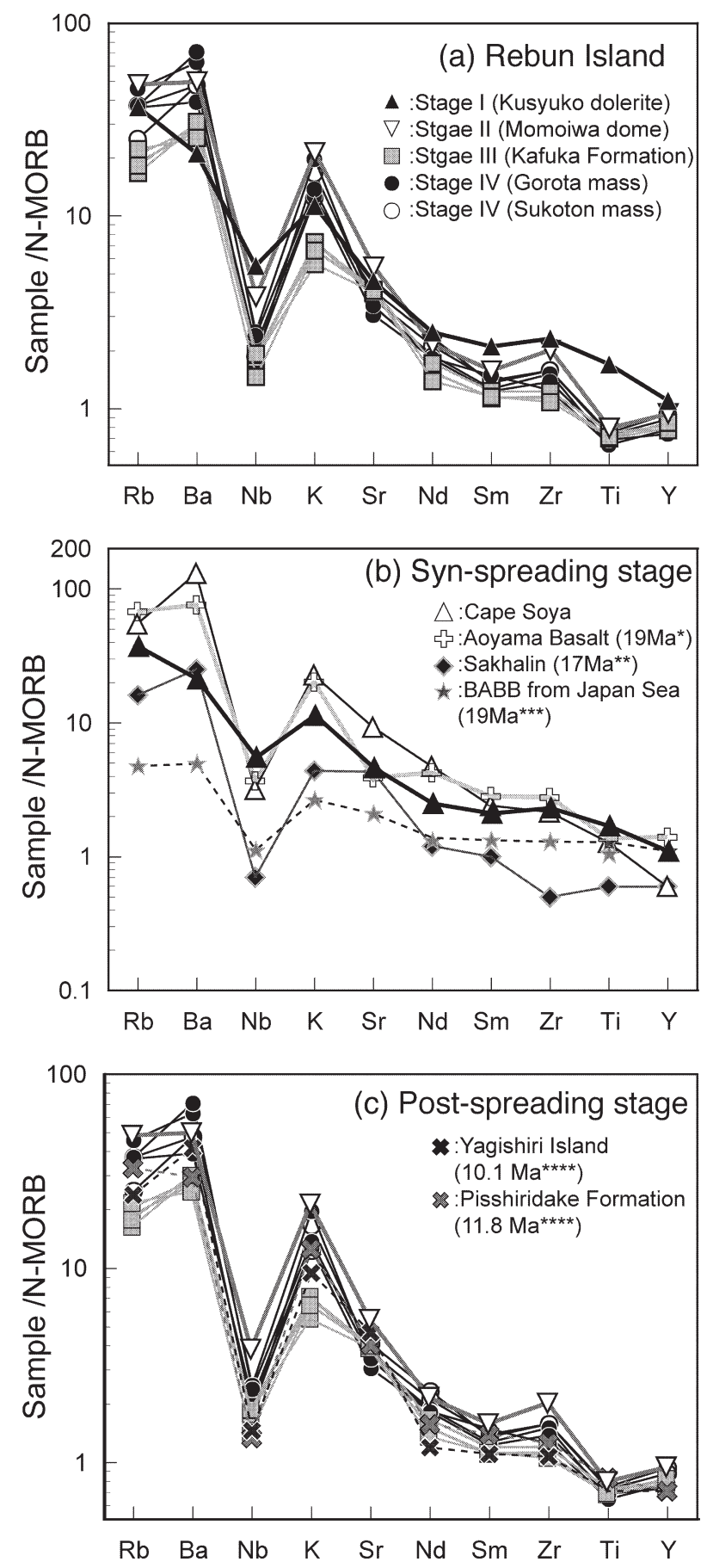

Figure 6. Abundance patterns of incompatible elements in the igneous rocks from Rebun Island normalized to N-MORB (Sun and McDonough, 1989). (a) Rebun Island and (b) Stage I rocks of Rebun Island with basalts from Cape Soya (Y. Hirahara, unpublished data), Hamamasu (Aoyama basalt: Okamura et al., 1991; Okamura et al., 2000), Sakhalin (Okamura et al., 2005), and Japan Sea (Pouclet et al., 1995) that erupted during the spreading of the Japan Sea back-arc basin. (c) Stages II-IV rocks of Rebun Island with basalts from Yagishiri Island and Pisshiridake Formation (Shuto et al., 2004) that erupted post-spreading. The K-Ar ages have been obtained from ${ }^{*}$, Okamura et al. (2000); ${ }^{* *}$, Okamura et al. (2005); ${ }^{* * *}$, Pouclet et al. (1995); and ${ }^{* * * *}$, Goto et al. (1995).

\section{DISCUSSION}

\section{Fractional crystallization processes}

The major and trace element trends observed for the Stage III and IV rocks can be explained by considering crystal fractionation. The differences between the trends of the two stages (Figs. 4 and 5) probably reflect the operation of different fractional crystallization processes.

To investigate this hypothesis, we used a leastsquares method to perform model calculations for the major element composition of the rocks (Wright and Doherty, 1970); the results are listed in Table 3. For each stage, the compositions of the parent and daughter magmas were selected by considering the basaltic rocks with the highest NdI values (St07 in Stage III and Su11 in Stage IV) and andesitic rocks with the lowest NdI values (St12 in Stage III and Sc213 in Stage IV), respectively (the reason for this approach is explained in the following section). The compositions of the fractionated phases, plagioclase, clinopyroxene, and orthopyroxene were the average compositions of phenocryst cores in the parent rocks. Because there were no fresh olivine phenocrysts in the studied rocks, we used olivine compositions that were in equilibrium with the whole-rock composition of each parent sample (Roder and Emslie, 1970).

The calculated sum of squares were less than 1.0 for both Stages III (0.03) and IV (0.42), and the results indicate that the compositional variation within rocks from both the stages mainly reflects the extent of fractionation of phenocryst minerals. Moreover, the contrasting variation trends for $\mathrm{FeO}^{*}, \mathrm{TiO}_{2}$, and $\mathrm{V}$ between the Stage III and the Stage IV rocks can be explained by the fractionation of varying amounts of Fe-Ti oxides (Stage III: 3.5\%, Stage IV: 1.0\%; Table 3).

\section{Crust contamination}

The variations of the $\mathrm{SrI}$ and $\mathrm{NdI}$ values with the $\mathrm{SiO}_{2}$ content for the Stage IV rocks (Fig. 8) are interpreted to reflect contamination, such as that expected via AFC processes (DePaolo, 1981). Using the parent and daughter magmas defined above (see Table 3), the contaminant was interpreted to be Hokkaido crustal rock (Maeda and Kagami, 1994) and shallow sedimentary rock (Suzuki et al., 2004).

Figure 9 shows a comparison of the correlation between the SrI and 100/Sr values of the samples from Rebun Island with the calculated AFC lines. Because 100/Sr does not vary significantly in the Stage III rocks, their variation shows a subvertical trend. On the other hand, the Stage IV rocks exhibit a wide range of both SrI and 100/ 
Ndl

(a)

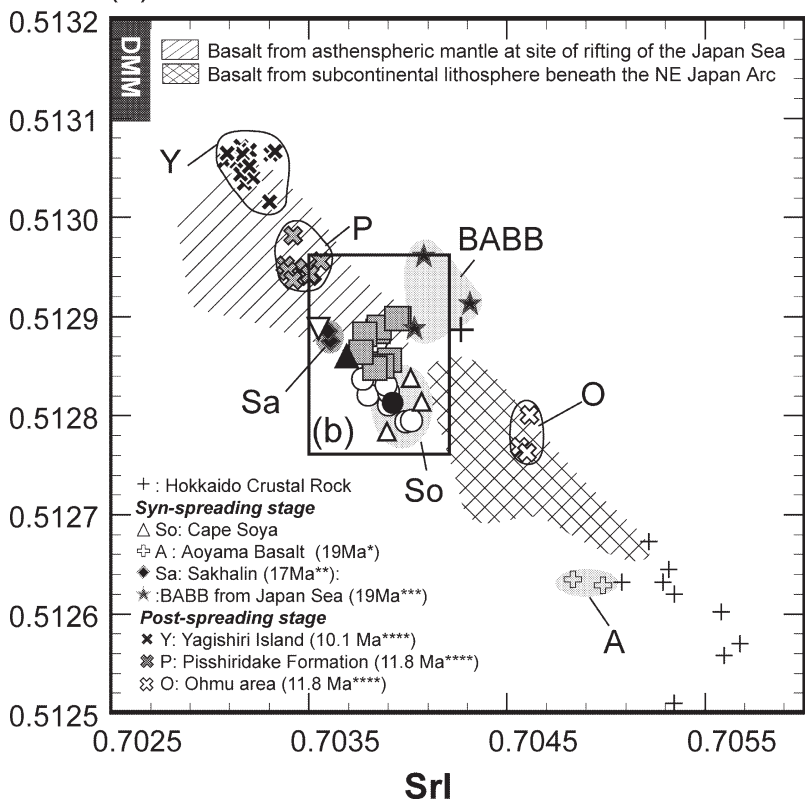

(b)

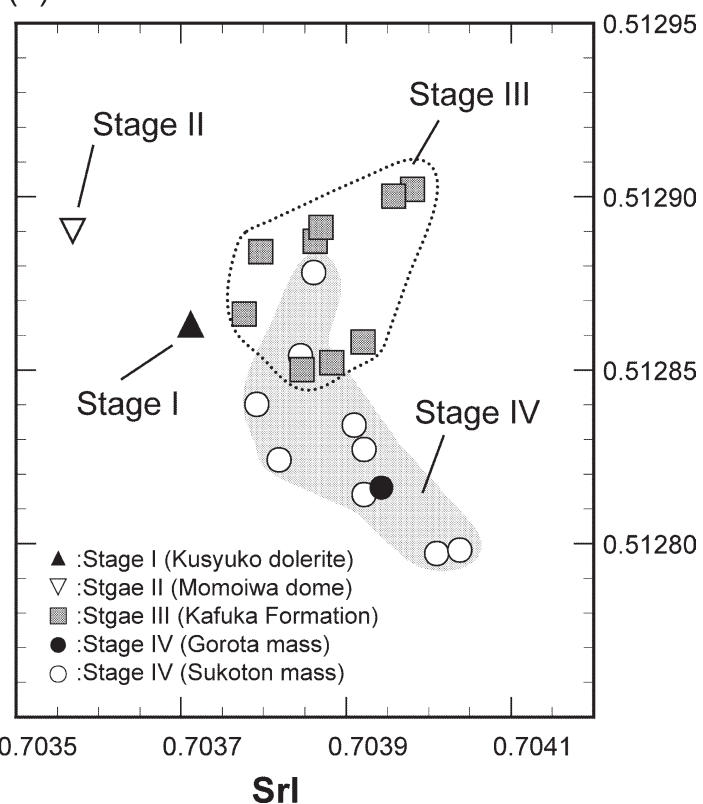

Figure 7. (a) SrI versus NdI diagram for igneous rocks from Rebun Island together with data for basaltic rocks from Cape Soya (Y. Hirahara, unpublished data), Yagishiri Island (Shuto et al., 2004), Pisshiridake Formation (Shuto et al., 2004), Hamamasu (Aoyama basalt: Okamura et al., 1991; Okamura et al., 2000), Sakhalin (Okamura et al., 2005), the Japan Sea (Pouclet et al., 1995), and Hokkaido crustal rock (granulites) (Maeda and Kagami, 1994). The grey-shaded field and the fields indicated by a solid line represent the compositional ranges of rocks that erupted in the syn- and post-spreading stage of the Japan Sea back-arc basin, respectively. The DMM fields are adopted from Hart (1988). The K-Ar ages have been obtained from ", Okamura et al. (2000); ${ }^{* *}$, Okamura et al. (2005); ${ }^{* * *}$, Pouclet et al. (1995); and ${ }^{* * * *}$, Goto et al. (1995). (b) SrI versus NdI diagram for the igneous rocks from Rebun Island. Fields indicated by the dotted line and the grey-shaded field indicate the compositional ranges in the Stage III and IV rocks, respectively.

Sr values; a plot of these values show a horizontal trend. Hokkaido crustal rocks show higher Sr isotopic ratios, but their Sr contents are similar to those of the Rebun Island samples. Therefore, the calculated AFC line $[r$ (ratio of assimilation to crystallization rate) $=0.2]$ between the crustal rock and Sul1 shows a subvertical trend. In contrast, the shallow sedimentary rock has relatively high $\mathrm{Sr}$ isotopic ratios and low Sr content (Suzuki et al., 2004), resulting in a positive sloping AFC line $(r=0.2)$.

In Figure 9, the trend exhibited by the Stage IV samples strongly correlates with the calculated AFC line involving shallow sedimentary rock. The predicted range of fractional crystallization (up to approximately $60 \%$ ) is in good agreement with the results of the least-squares model (Table 3). This indicates that AFC processes involving shallow sedimentary rock can explain the SrI trend for Stage IV andesitic rocks. Hirahara and Shuto (2003) reported that Stage IV rocks (Sukoton mass) are intruded into the wet, poorly consolidated sediment of Hamanaka Formation; the rocks appear to have assimilated the sediment during the fractional crystallization.

\section{Origin of the differences between Stage III and IV magmas}

The $\mathrm{MgO}, \mathrm{Cr}$, and Ni contents of the Stage III basaltic rocks are lower than those of the Stage IV basaltic rocks. Significant fractional crystallization of olivine is indicated in these samples by their low $\mathrm{MgO}$ contents; meaning that their bulk chemical compositions are not in equilibrium with the composition of mantle olivine $\left(\mathrm{Fo}_{9_{0}}\right)$, and that their $\mathrm{Ni}$ and $\mathrm{Cr}$ contents are lower than those of primary basalt magmas produced from mantle peridotite (Frey et al., 1978; Hart and Davis, 1978). A comparison of the $\mathrm{MgO}$ and Ni contents of the Stage III and IV basaltic rocks suggests that early olivine fractionation was more pronounced in Stage III than in Stage IV.

As compared to the Stage III basaltic rocks, the Stage IV rocks show elevated absolute concentrations of the incompatible elements. The Stage IV rocks (excluding andesitic rocks) show SrI and NdI values similar to those of the Stage III rocks (Figs. 7 and 8). When normalized to $\mathrm{N}-\mathrm{MORB}$, the resulting abundance patterns for the incompatible elements (Fig. 6a) in the Stage IV rocks are typical for subduction-related lavas and identical to those for the Stage III rocks. These similarities indicate that 


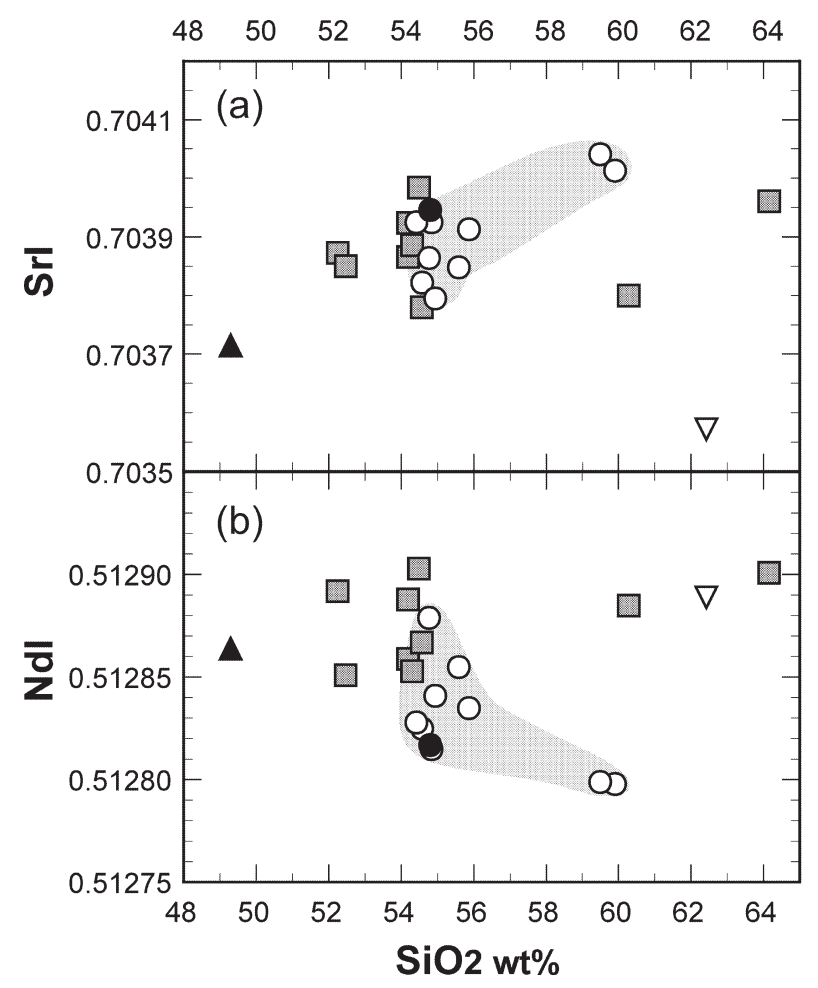

$\Delta$ : Stage I (Kusyuko dolerite), $\nabla$ : Stage II (Momoiwa dome), $\square$ : Stage III (Kafuka Formation), ๑: Stage IV (Gorota mass), O: Stage IV (Sukoton mass)

Figure 8. Diagrams of $\mathrm{SiO}_{2}$ versus (a) $\mathrm{SrI}$ and (b) NdI. The greyshaded fields indicate the compositional ranges of the Stage IV rocks. The SrI and NdI values for the Stage III rocks are constant with an increase in $\mathrm{SiO}_{2}$, whereas the $\mathrm{SrI}$ and $\mathrm{NdI}$ values of Stage IV rocks increase and decrease with an increase in the $\mathrm{SiO}_{2}$, respectively.

Stage III and IV basaltic melts may have originated from different degrees of partial melting of the same source.

Figure 10 shows $\mathrm{Zr} / \mathrm{Nb}$ and $\mathrm{Y} / \mathrm{Nb}$ ratios plotted against the $\mathrm{Nb}$ content for the samples from Rebun Island. The Stage III and IV rocks have similar $\mathrm{Zr} / \mathrm{Nb}$ ratios, which do not change with an increase in the $\mathrm{Nb}$ content. In contrast, $\mathrm{Y} / \mathrm{Nb}$ ratios of the Stage III rocks decreases with an increase in the $\mathrm{Nb}$ content and are higher than that in the Stage IV rocks for a given $\mathrm{Nb}$ content.

By considering the partition coefficients of $\mathrm{Zr}, \mathrm{Y}$, and $\mathrm{Nb}$ among olivine, orthopyroxene, and clinopyroxene in a basaltic melt (Pearce and Norry, 1979; Rollinson, 1993; Green, 1994), the decrease in $\mathrm{Y} / \mathrm{Nb}$ obtained for Stage III and IV rocks can be explained in terms of the fractionation of these phases. In the case of a basaltic melt derived from the partial melting of mantle peridotite composed of olivine, orthopyroxene, and clinopyroxene, the incompatibility of $\mathrm{Nb}$ is higher than that of $\mathrm{Y}$, but similar to that of $\mathrm{Zr}$. Thus, the different $\mathrm{Y} / \mathrm{Nb}$ rarios but similar $\mathrm{Zr} / \mathrm{Nb}$ ratios at a given $\mathrm{Nb}$ content suggest that the Stage
III and IV rocks are originated from different degrees of partial melting of a single source.

\section{Magmatic activity and origin of the source of Miocene igneous rocks from Rebun Island}

Magmatic evolution associated with the spreading of the Japan Sea back-arc basin has also been reported from the East Asian continental margin area (e.g., Pouclet et al., 1995; Tatsumi et al., 2000; Okamura et al., 2005).

It has been suggested that temporal changes occur in the source of Tertiary-Quaternary basaltic rocks of the back-arc side of the NE Japan arc in association with the spreading of the Japan Sea back-arc basin (e.g., Kurasawa and Konda, 1986; Nohda and Wasserburg, 1986; Nohda et al. 1988; Tatsumi et al., 1988; Shuto et al., 1993; Shuto et al., 2006). These studies point out that the $\mathrm{Sr}-\mathrm{Nd}$ isotopic compositions of basaltic rocks changed from high $\mathrm{Sr}$ and low $\mathrm{Nd}$ compositions to low $\mathrm{Sr}$ and high $\mathrm{Nd}$ isotopic compositions at around $15 \mathrm{Ma}$. It is inferred that the former composition originated from the enriched subcontinental lithospheric mantle beneath the NE Japan arc, whereas the latter originated from the upwelling of depleted asthenospheric mantle (Fig.7a); this upwelling caused the thinning of the lithosphere and the resultant spreading that lead to the formation of the Japan Sea back-arc basin.

Previous researchers have also reported the relation between the temporal changes in the Miocene magmatic activity in Hokkaido in terms of the spreading of the Japan Sea (or Kurile basin) (e.g., Goto et al., 1995; Ikeda, 2000; Okamura et al., 2000; Shuto et al., 2004). Shuto et al. (2004) reported that basaltic rocks younger than $12 \mathrm{Ma}$ in northern Hokkaido have SrI and NdI values similar to the basaltic rocks that originated from the asthenospheric mantle beneath the NE Japan arc. However, there are also some basaltic rocks with higher SrI and lower NdI compositions in the Ohmu volcanic zone. In the context of the asthenospheric mantle upwelling beneath the NE Japan arc, Shuto et al. (2004) inferred that the former were originated from the upwelling of asthenospheric mantle at the sites of spreading in the Japan Sea, whereas the latter were derived from enriched subcontinental lithosphere (Fig.7a). Okamura et al. (2000) also reported a change in the magma source (between 4 and $6 \mathrm{Ma}$ ) of the Central Hokkaido area, from a source enriched in the incompatible elements to one depleted. They also attributed Pliocene volcanism to asthenospheric upwelling at the arc-arc junction. Okamura et al. (2005) proposed that the different generations of basalts (pre- and syn-spreading of the Japan Sea) that erupted in Central Sikhote-Alin and Sakhalin recorded a change in the source material from 
Table 3. Results of least-square calculations for the (a) Stage III and (b) Stage IV samples from Rebun Island (after Wright and Doherty, 1970)

\begin{tabular}{|c|c|c|c|c|c|c|c|c|c|c|}
\hline & Proportion (\%) & $\mathrm{SiO}_{2}$ & $\mathrm{TiO}_{2}$ & $\mathrm{Al}_{2} \mathrm{O}_{3}$ & $\mathrm{FeO}^{*}$ & $\mathrm{MgO}$ & $\mathrm{CaO}$ & $\mathrm{Na}_{2} \mathrm{O}$ & $\mathrm{K}_{2} \mathrm{O}$ & $\mathrm{P}_{2} \mathrm{O}_{5}$ \\
\hline St12 & 28.7 & 60.3 & 0.85 & 17.7 & 6.4 & 2.6 & 7.34 & 3.62 & 0.82 & 0.22 \\
\hline Olivine & 0.00 & 38.9 & 0.00 & 0.00 & 20.4 & 40.7 & 0.00 & 0.00 & 0.00 & 0.00 \\
\hline Augite & 5.27 & 51.4 & 0.40 & 3.35 & 5.27 & 16.8 & 22.0 & 0.21 & 0.00 & 0.00 \\
\hline Orthopyroxene & 20.4 & 53.7 & 0.27 & 1.21 & 18.0 & 25.0 & 1.96 & 0.02 & 0.00 & 0.00 \\
\hline Plagioclase & 42.2 & 50.6 & 0.00 & 31.4 & 0.72 & 0.12 & 14.6 & 2.80 & 0.10 & 0.00 \\
\hline Fe-oxide & 2.82 & 0.00 & 0.00 & 0.00 & 100 & 0.00 & 0.00 & 0.00 & 0.00 & 0.00 \\
\hline Ti-oxide & 0.67 & 0.00 & 100 & 0.00 & 0.00 & 0.00 & 0.00 & 0.00 & 0.00 & 0.00 \\
\hline Calculated composition & & 52.3 & 0.99 & 18.7 & 8.89 & 5.91 & 9.53 & 3.38 & 0.29 & 0.06 \\
\hline St07 & & 52.3 & 0.95 & 18.7 & 8.85 & 5.89 & 9.45 & 3.39 & 0.22 & 0.16 \\
\hline Difference & & -0.04 & -0.04 & -0.01 & -0.04 & -0.02 & -0.08 & 0.01 & -0.07 & 0.10 \\
\hline Sum of squares & & 0.03 & & & & & & & & \\
\hline \multicolumn{11}{|c|}{ (b) Su11=Sc213+ Olivine + Augite + Orthopyroxene + Plagioclase + Fe-Ti oxides } \\
\hline & Proportion $(\%)$ & $\mathrm{SiO}_{2}$ & $\mathrm{TiO}_{2}$ & $\mathrm{Al}_{2} \mathrm{O}_{3}$ & $\mathrm{FeO}^{*}$ & $\mathrm{MgO}$ & $\mathrm{CaO}$ & $\mathrm{Na}_{2} \mathrm{O}$ & $\mathrm{K}_{2} \mathrm{O}$ & $\mathrm{P}_{2} \mathrm{O}_{5}$ \\
\hline $\mathrm{Sc} 213$ & 40.0 & 59.9 & 1.44 & 15.0 & 8.35 & 3.45 & 5.09 & 4.45 & 1.86 & 0.35 \\
\hline Olivine & 0.00 & 40.1 & 0.00 & 0.00 & 14.1 & 45.8 & 0.00 & 0.00 & 0.00 & 0.00 \\
\hline Augite & 3.67 & 52.5 & 0.47 & 2.05 & 7.79 & 16.8 & 19.1 & 0.26 & 0.00 & 0.00 \\
\hline Orthopyroxene & 19.0 & 53.7 & 0.42 & 1.24 & 18.1 & 25.4 & 2.08 & 0.03 & 0.00 & 0.00 \\
\hline Plagioclase & 36.3 & 51.5 & 0.04 & 30.4 & 0.63 & 0.13 & 14.1 & 3.60 & 0.12 & 0.00 \\
\hline Fe-oxide & 0.74 & 0.00 & 0.00 & 0.00 & 100 & 0.00 & 0.00 & 0.00 & 0.00 & 0.00 \\
\hline Ti-oxide & 0.31 & 0.00 & 100 & 0.00 & 0.00 & 0.00 & 0.00 & 0.00 & 0.00 & 0.00 \\
\hline Calculated composition & & 54.8 & 1.00 & 17.3 & 8.02 & 6.24 & 8.16 & 3.79 & 0.80 & 0.14 \\
\hline Sul1 & & 54.8 & 0.95 & 17.1 & 7.97 & 0.17 & 6.07 & 8.44 & 3.33 & 0.89 \\
\hline Difference & & 0.00 & -0.05 & -0.24 & -0.05 & -6.07 & -2.10 & 4.64 & 2.53 & 0.75 \\
\hline Sum of squares & & 0.42 & & & & & & & & \\
\hline
\end{tabular}

lithospheric to asthenospheric mantle.

Because samples from all the igneous activity stages of Rebun Island have the same SrI and NdI values, it is possible that they were derived from a single source. These values fall within the field of basalts from Cape Soya, Sakhalin, and some of the samples form the Japan Sea that were contemporaneously generated with the spreading of the Japan Sea. Previous study indicates that of these basaltic rocks originated from a depleted asthenospheric mantle, similar to that beneath the back-arc side of the NE Japan arc (Pouclet et al., 1995; Okamura et al., 2005). Therefore, the source during all stages of magmatism on Rebun Island was the depleted asthenospheric mantle.

The abundance pattern of the incompatible elements in the Stage I sample is different from those of the Stages II-IV (Fig. 6a) and it is compared with the patterns of other syn-spreading stage lavas in Figure 6b. However, within the syn-spreading basalts, there is someare geochemical variations, which that suggests the involvement of different sources. Because the Aoyama basalts have high SrI and low NdI values, high large -ion lithophile element (LILE) concentrations (Figs. 6b and 7), they were inferred that they originated from the melting of the sub- continental lithosphere (Okamura et al., 2000). In contrast, basaltic rocks from Sakhalin, Cape Soya, and the Japan Sea have lower SrI and higher NdI compositions (similar to the basalts from back-arc side in NE Japan) as compared to those in the Aoyama basalts, and the observations indicate that they were derived from an upwelling of the depleted asthenospheric mantle. The basalts from Cape Soya and Sakhalin are characterized by relatively low concentrations of HFSEs with respect to the LILEs and are depleted in $\mathrm{Nb}$ and $\mathrm{Y}$ relative to the back-arc basin basalt (BABB) from the Japan Sea. Okamura et al. (2005) proposed that Sakhalin basalts (the Early-Middle Miocene) were derived from a depleted asthenospheric mantle source that is closely associated with the influx of LILE-enriched, but HFSE-depleted subduction-related melts or fluids. Although the Stage I rock has higher concentrations of the incompatible elements than those of BABB from the Japan Sea, the pattern for the Stage I rock is more similar to that for BABB. Thus, the Stage I rocks probably derived from the depleted asthenospheric mantle as a result of the magmatic activity related to the spreading of the back-arc basin.

The abundance patterns of the incompatible elements in the Stage II, III, and IV rocks indicate that the activity 


\section{Srl}

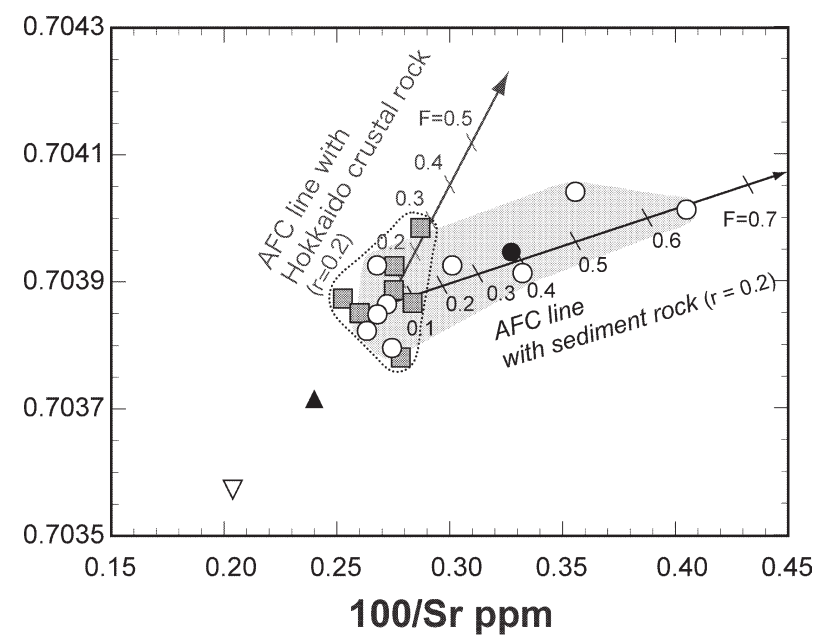

$\Delta$ : Stage I (Kusyuko dolerite), $\nabla$ : Stage II (Momoiwa dome), $\square$ : Stage III (Kafuka Formation), : Stage IV (Gorota mass), O: Stage IV (Sukoton mass)

Figure 9. Plot for 100/Sr versus SrI for the igneous rocks from Rebun Island. The grey and black solid arrows indicate the calculated AFC variation trends for the parent (Su11) of the Stage IV rocks with assimilation of Hokkaido crustal rock ${ }^{87} \mathrm{Sr} /{ }^{86} \mathrm{Sr}$ : 0.7056; Sr: 330 ppm; Maeda and Kagami, 1994) and sedimentary rock $\left({ }^{87} \mathrm{Sr} /{ }^{86} \mathrm{Sr}\right.$ : 0.7103; Sr: 28 ppm; Suzuki et al., 2004), respectively. The numbers represent the degree of fractionation $(\mathrm{F})$. The fractionated mineral assemblages and partition coefficients of $\mathrm{Sr}$ $\left(\mathrm{D}_{\mathrm{Sr}(\mathrm{P} / \mathrm{L})}\right.$ of 1.12) are obtained from the results of least-squares modeling (Table 3). Fields indicated by the dotted line and greyshaded field represent the compositional ranges for Stage III and IV rocks, respectively.

that generated these magmas was related to subduction. Previous researchers have demonstrated that the magmatism in northern Hokkaido from 14 to 9 Ma was dominated by the activity in a subduction-zone setting. However, the basaltic rocks from Yagishiri Island and the Pisshiridake Formation also have geochemical signatures that are typical of subduction-related magmatism (Fig. 6c); this is despite the basaltic rocks from Yagishiri Island having lower SrI and higher NdI values, and those from the Pisshiridake Formation have lower $\mathrm{SrI}$ and higher NdI values as compared to the Stage II, III, and IV rocks (Fig. 7). These differences could reflect the contamination of basaltic magma by crustal material or heterogeneities in the magma source beneath northern Hokkaido. The above discussion should be carefully considered in future studies.

\section{CONCLUSIONS}

We divided the Miocene magmatic activity on Rebun Island into four stages. Stage III and IV rocks show a large variation of geochemical compositions that can be ex-

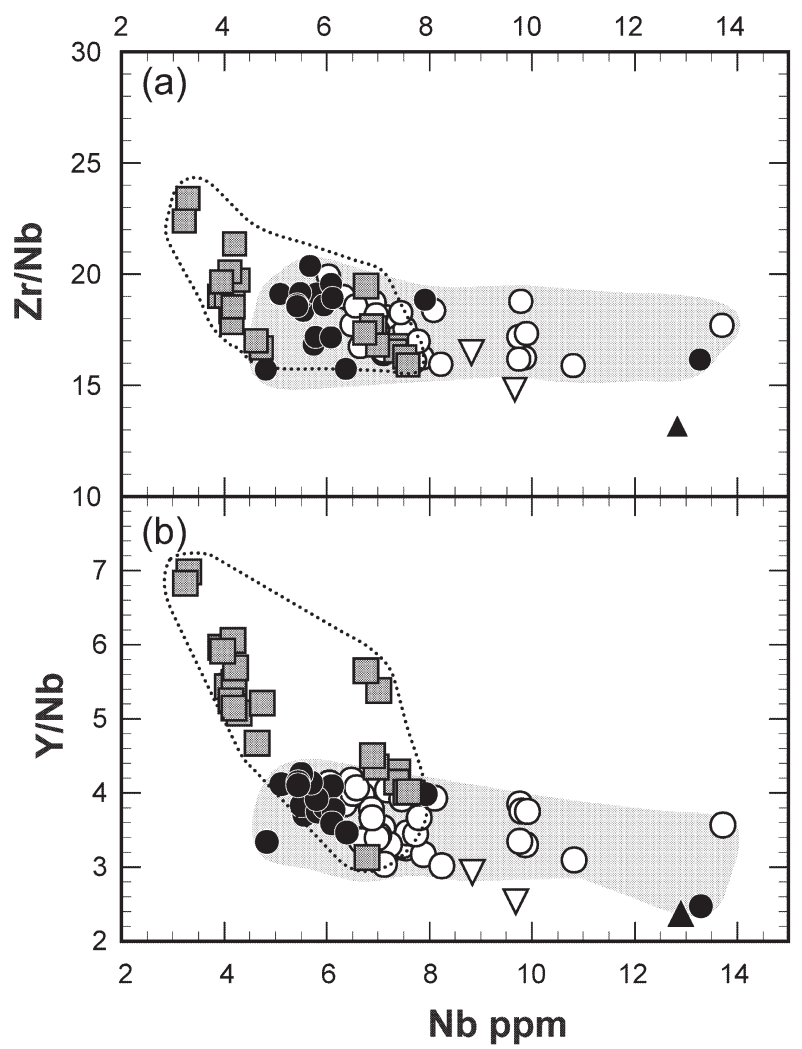

A: Stage I (Kusyuko dolerite), $\nabla$ : Stage II (Momoiwa dome), ㅁ: Stage III (Kafuka Formation), ๑: Stage IV (Gorota mass), O: Stage IV (Sukoton mass)

Figure 10. Plots of $\mathrm{Nb}$ concentrations versus (a) $\mathrm{Zr} / \mathrm{Nb}$ and (b) $\mathrm{Y} /$ $\mathrm{Nb}$ ratios for the samples from Rebun Island. Fields indicated by the dotted line and grey-shaded field indicate the compositional ranges for the Stage III and IV rocks, respectively. The ratios of $\mathrm{Zr} / \mathrm{Nb}$ for the Stage III rocks are similar to those for the Stage IV rocks. However, the ratios of $\mathrm{Y} / \mathrm{Nb}$ for the former are higher than those for the latter.

plained by considering the fractional crystallization of a primitive melt. The differences in the major and trace element signatures of the Stage III and IV rocks result from the fractionation of mineral phases in varying amounts and the different degrees of partial melting of the source material. The high SrI and low NdI values of the Stage IV andesitic rocks are attributed to AFC involving sedimentary rocks.

Previous studies carried out in the East Asian continental margin area have described the occurrence of temporal changes in the magma source that are related to the spreading of the Japan Sea back-arc basin. However, the rocks from all the four stages on Rebun Island have similar SrI and NdI values, indicating that changes did not occur in the sources of the Miocene magmatic activity on Rebun Island. The rocks from Rebun Island have SrI and NdI values similar to those of basaltic rocks derived from the depleted asthenospheric mantle during the spreading 
of the Japan Sea. The incompatible element signatures of Stage I rock are similar to those of BABBs such as those in the Japan Sea. On the other hand, the Stage II, III, and IV rocks show incompatible element patterns similar to basaltic rocks that originated from subduction-related magmatism in northern Hokkaido from 14 to 9 Ma.

\section{ACKNOWLEDGMENT}

We express our gratitude to Profs. H. Kagami, S. Miyashita, E. Takazawa, and T. Shimura of Niigata University for their valuable input over the course of several discussions. We also extend our thanks to Dr. M. Yuhara of Fukuoka University for his helpful suggestions and assistance with the $\mathrm{Sr}$ and $\mathrm{Nd}$ isotope analyses. We thank A. Nichols of JAMSTEC for reviewing the English language and improving the manuscript. We also thank J.-I. Kimura of associate editor and two anonymous reviewers for their constructive and critical reviews of the manuscript.

\section{REFERENCES}

DePaolo, D.J. (1981) Trace element and isotopic effects of combined wall rock assimilation and fractional crystallization. Earth and Planetary Science Letters, 53, 189-202.

Frey, A., Green, D.H. and Roy, S.D. (1978) Integrated models of basalt peterogenesis: a study of quartz tholeiite to olivine melilities from South Eastern Australia utilizing geochemical and experimental petrogical data. Journal of Petrology, 19, 463-513.

Gill, J.B. (1981) Orogenic andesite and plate tectonics. pp. 390, Springer Verlag, Berlin.

Goto, Y. (1997) Interlayered sill-sediment structure at the base of a Miocene basaltic andesite sheet intrusion, Rebun Island, Hokkaido, Japan. Journal of Mineralogy, Petrology and Economic Geology, 92, 509-520.

Goto, Y. and Wada, K. (1991) The middle Miocene alkali dolerite from Rebun Island, northeastern Japan Sea. Journal of Mineralogy. Petrology and Economic Geology, 86, 375-378.

Goto, Y., Nakagawa, M. and Wada, K. (1995) Tectonic setting of the Miocene volcanism in the northern Hokkaido district, Japan: speculation from their $\mathrm{K}-\mathrm{Ar}$ ages and major element chemistry. Journal of Mineralogy, Petrology and Economic Geology, 90, 109-123 (in Japanese with English abstract).

Goto, Y. and McPhie, J. (1998) Endogenous of a Miocene submarine dacite cryptdome, Rebun Island, Hokkaido, Japan. Journal of Volcanology and Geothermal Research, 84, 273-286.

Green, H.T. (1994) Experimental studies of trace-element partitioning applicable to igneous petrogenesis - Sedona 16 years later. Chemical Geology, 117, 1-36.

Hamamoto, T., Yuhara, M., Miyazaki, T., Fukase, M., Kondo, H., Ikawa, T., Ishioka, J., Kagami, H. and Shuto, K. (2000) Rb, $\mathrm{Sr}, \mathrm{Sm}$ and $\mathrm{Nd}$ separation from rocks, minerals and natural water using ion-exchange resin. Science Report Niigata University, Serch E (Geology), 15, 49-58.

Hart, S. (1988) Heterogeneous mantle domains: signatures, genesis and mixing chronologies, Earth and Planetary Science Letters, 90, 273-296.
Hart, S.R. and Davis, K.E. (1978) Nickel partitioning between olivine and silicate melt. Earth and Planetary Science Letters, 40, 203-219.

Hirahara, Y. and Shuto, K. (2003) Internal structure and formation of the Cape Sukoton doleritic intrusion, Rebun Island, Hokkaido, Japan. Journal of Geological Society of Japan, 109, 442-458 (in Japanese with English abstract).

Ikeda, Y. (1998) Geochemistry of Miocene back-arc basin basalts from northeast Hokkaido, Japan. Journal of the Geological Society of Japan, 104, 99-106.

Ikeda, Y., Stern, R.J., Kagami, H. and Sum, C.H. (2000) Pb, Nd and $\mathrm{Sr}$ isotopic compositions on the origin of Miocene basaltic rocks from northeast Hokkaido, Japan: Implications for opening of the Kurile back-arc basin. The Island Arc, 9, 161-172.

Kagami, H., Iwata M., Sano S. and Honma H. (1987) Sr and Nd isotopic compositions and $\mathrm{Rb}, \mathrm{Sr}, \mathrm{Sm}$ and $\mathrm{Nd}$ concentrations of standard samples. Technical Report ISEI, Okayama University, Series B4, 165-177.

Kagami H., Yokose H. and Honma H. (1989) ${ }^{87} \mathrm{Sr} /{ }^{86} \mathrm{Sr}$ and ${ }^{143} \mathrm{Nd} /$ ${ }^{144} \mathrm{Nd}$ ratios of GSJ rock reference samples; JB1-a, JA-1 and JG-1a. Geochemical Journal, 23, 209-214.

Kimura, S., Shikazono, N., Kashiwagi, H. and Nohara, M. (2004) Middle Miocene-early Pliocene paleo-oceanic environment of Japan Sea deduced from geochemical features of sedimentary rocks. Sedimentary Geology, 164, 105-129.

Kokubu, K., Okamura, S., Yahata, M., Furuyama K. and Nagao, K. (1994) Petrological variation with time and space in the Neogene volcanic rocks from east Hokkaido. Journal of Geological Society of Japan, 100, 658-674 (in Japanese with English abstract).

Komatsu, M. (1985) Structural framework of the axial zone in Hokkaido - its composition, chatacterscharacters and tectonics -. Memoirs of the Geological Society of Japan, 25, $137-155$.

Kuno, H. (1968) Differentiation of basalt magmas. In Hess, H. H. and Poldervaart, A., eds., Basalts: the Poldervaart treatise on rocks of basaltic composition. Wiley-Interscience, New York, 623-688

Kurasawa, H. and Konda, T. (1986) Strontium isotopic ratios of Tertiary volcanic rocks of northeastern Honshu, Japan: implication for the spreading of the Japan Sea. Journal of Geological Society of Japan, 92, 205-217 (in Japanese with English abstract).

Lungmair, G.W. and Mariti, K. (1978) Lunar initial ${ }^{143} \mathrm{Nd} /{ }^{144} \mathrm{Nd}$ : differential evolution the lunner crust and mantle. Earth and Planetary Science Letters, 39, 349-357.

Maeda, J. and Kagami, H. (1994) Mafic igneous rocks derived from N-MORB source mantle, Hidaka magmatic zone, Central Hokkaido: $\mathrm{Sr}$ and $\mathrm{Nd}$ isotopic evidence. Journal of Geological Society of Japan, 100, 185-188.

Miyashiro, A. (1978) Nature of Alkalic Volcanic Rock Series, Contributions to Mineralogy and Petrology, 66, 91-104.

Miyazaki, T. and Shuto, K. (1998). Sr and Nd isotope of twelve GSJ rock reference sample using MAT262 mass spectrometer. Geochemical Journal, 32, 345-350.

Nakagawa, M., Goto, Y., Arai, K., Wada, K. and Itaya, T. (1993) $\mathrm{K}-\mathrm{Ar}$ ages and major element chemical compositions of Late Miocene and Pliocene basalts from Takikawa district, central Hokkaido: Basaltic monogenetic volcano group at the junction of the northeastern Japan and Kurile arcs. Journal of Mineralogy, Petrology and Economic Geology, 88, 390-401 
(in Japanese with English abstract).

Noda, Y. and Hoyanagi, K. (1993) Molluscan fauna from the Miocene Meshikuni Formation on Rebun Island, northern Hokkaido. Transactions and Proceedings of the Palaeontological Society of Japan, New Series, 172, 311-327.

Nohda, S. and Wasserburg, G.J. (1986) Trends of Sr and Nd isotopes through time near the Japan Sea in northeastern Japan. Earth and planetary Science Letters, 78, 157-167.

Nohda, S., Tatsumi, Y., Otofuji, Y., Masuda, T. and Ishizaka, K. (1988) Asthenospheric injection and back-arc opening: isotopic evidence from northeast Japan. Chemical Geology, 68, 317-327.

Okamura, S., Takahashi, N., Saito, N., Yahata, M., Kagami, H. and Kabato Collaborative Research Group (1991) Miocene tholeiitic basalt from Kabato district, Hokkaido, Japan. Earth Science; Chikyu Kagaku, 45, 399-414 (in Japanese with English abstract).

Okamura, S., Sugawara, M. and Kagami, H. (1995) Origin and spatial variation of Miocene volcanic rocks from north Hokkaido, Japan. Memoirs of the Geological Society of Japan, 44, 165-180 (in Japanese with English abstract).

Okamura, S., Martynov, Y.A., Furuyama, K. and Nagao, K. (1998) $\mathrm{K}-\mathrm{Ar}$ ages of the basaltic rocks from Far Eat Russia: constraints on the tectonic-magamtism associated with the Japan Sea opening. The Island Arc, 7, 271-282.

Okamura, S., Sekine, H., Arai, K., Yamamoto, M., Nishido, H. and Yahata, M. (2000) K-Ar ages and geochemistry of the Cenosoic volcanic tocks from Hamamasu are, central Hokkaido, Japan-temporal changes in magma geochemistry resulted from tectonics of arc-arc junction-, Journal of Geological Society of Japan, 106, 330-346 (Japanese with English abstract).

Okamura, S., Arculus, R.J. and Martynov, Y.A. (2005), Cenozoic magmatism of the North-Eastern Eurasian margin: the role of lithosphere versus Asthenosphere. Journal of Petrology, 46, 221-253.

Otofuji, Y. and Masuda, T. (1984) Timing of rotational motion of southwest Japan inferred from paleomagnetism. Earth and Palanetary Science Letteres, 70, 373-382.

Otofuji, Y., Kambara, A., Masuda, T. and Nohda, S. (1994) Counterclockwise rotation of northwest Japan: Paleomagnetic evidence for regional extent and timing of rotation. Earth and Planetary Science Letters, 121, 503-518.

Pearce, J.A. and Norry, M.J. (1979) Petrogenetic implications of $\mathrm{Ti}, \mathrm{Zr}, \mathrm{Y}$, and $\mathrm{Nb}$ vatiations in volcanic rocks. Contributions to Mineralogy and Petrology, 69, 33-47.

Pouclet, A., Lee, J.-S., Vidal, P., Cousens, B. and Bellon, H. (1995) Cretaceous to Cenozoic volcanism in South Korea and in the Sea of Japan: magmatic constraints on the opening of the back-arc basin. In: Smellie, J.L. Editor, Volcanism Associated with Extension at Consuming Plate Margins, Geological Society Special Publication, London, 169-191.

Roder, P.L. and Emslie, R.F. (1970) Olivine-liquid equilibrium. Contribution to Mineralogy and Petrology, 29, 275-289.

Rollinson, H. (1993) Using geochemical data: evaluation, presentation, interpretation. pp.352, Longman, Singapore.

Shuto, K., Ohki, J., Kagami, H., Yamamoto, M., Watanabe, N., Yamamoto, K., Anzai, N. and Itaya, T. (1993) The relationships between drastic change in $\mathrm{Sr}$ isotope ratios of magma sources beneath the NE Japan arc end the spreading of the Japan Sea back-arc basin. Mineralogy and Petrology, 49, 71-90.

Shuto, K., Hirahara, Y., Ishimoto, H., Aoki, A., Jinbo, A. and Goto,
Y. (2004) Sr and $\mathrm{Nd}$ isotopic compositions of the magma source beneath north Hokkaido, Japan: comparison with the back-arc side in the NE Japan arc. Journal of Volcanology and Geothermal Reserch, 134, 57-75.

Shuto, K., Ishimoto H., Hirahara,Y., Sato, M., Matsui, K., Fujibayashi, N., Takazawa, E., Yabuki, K., Sekine, Kato, M. and Rezanov, A.I. (2006) Secular variation of magma source during Early to Middle Miocene time in the Niigata area, NE Japan: Asthenospheric mantle upwelling during back-arc basin opening, Lithos, 86, 1-33.

Steiger, R.H. and Jäger, E. (1977) Subcommission on geochronology: convention on the use of decay constants in geo- and cosmo-chronology. Earth and Planetary Science Letters, 36, 297-302.

Sun, S-s. and McDonough, W.F. (1989) Chemical and isotopic systematics of oceanic basalt: implications for mantle composition and process. Magmatism in the Ocean Basin, A. D. \& Norry, M.J. (eds), Geological Sociey Special Publication , 42, 313-345.

Takahashi, T. and Shuto, K. (1997) Major and trace element analysis of silicate rocks using X-ray fluorescence spectrometer RIX 3000. The Rigaku Journal, 28, 25-37 (in Japanese).

Tamaki, K., Suyehiro, K., Allan, J., Ingle, C. and Pisciotte, K.A. (1992) Tectonic synthesis and implications of Japan Sea ODP drilling. In: Tamaki, K, Suyehiro, K., Allan, J. and McWilliarms, M. (eds) Proceeding of the Ocean Drilling Program, Scientific Results 127/128. College Station, TX: Ocean Drilling Program, pp. 1333-1348.

Tatsumi, Y., Nohda, S., and Ishizaka, K. (1988) Secular variation of magma source compositions beneath the Northeast Japan arc. Chemical Geology, 68, 309-316.

Tatsumi, Y., Sato, K., Sano, T., Arai, R. and Prikhodko, V.S., (2000) Transition from arc to intraplate magmatism associated with backarc rifting; evolution of the Sikhote Alin volcanism: Geophysical Research Letters 27, 1587-1590.

Watanabe, Y. (1995) A tectonic model for epithermal Au mineralization in NE Hokkaido, Japan. Research of Geology Special Issue, 18, 257-269.

Watanabe, Y. and Yamaguchi, S. (1988) K-Ar ages of Miocene volcanic rocks and the tectonics in the Nayoro-Asahikawa region, northern Hokkaido. Earth Science; Chikyu Kagaku, 42, 91-99 (in Japanese with English abstract).

Wright, T.L. and Doherty, P.C. (1970) A liner programming and least squares computer method for solving petrologic mixing problems. Geological Society of America Bulliten, 81, 19952008.

Yahata, M. and Nishido, H. (1995) Neogene volcanism and tectonics in the Monbetsu-Engaru district in the northeastern part of Central Hokkaido, Japan. Journal of the Geological Society of Japan, 101, 685-704 (in Japanese with English abstract).

Yamasihta, S., Shuto, K., Kakihara, Y. and Kagami, H. (1999) Coeval volcanism due to interaction of back-arc basin basalt (BABB) magma with the island-arc crust in the late Miocene Engaru volcanic field, northeastern Hokkaido, Japan: The evidence of $\mathrm{Sr}$ and $\mathrm{Nd}$ isotopic ratios combined with majorand trace- element compositions. Journal of Geological Society of Japan, 105, 625-642.

Manuscript received April 21, 2007

Manuscript accepted August 4, 2008

Manuscript handled by Jun-ichi Kimura 